\title{
Influences of the Industry 4.0 Revolution on the Human Capital Development and Consumer Behavior: A Systematic Review
}

\author{
Violeta Sima $^{1, *(\mathbb{D} \text {, Ileana Georgiana Gheorghe }}{ }^{1}$, Jonel Subić ${ }^{2}$ and Dumitru Nancu ${ }^{3}$ \\ 1 Petroleum-Gas University of Ploiesti, Blvd. Bucuresti, no. 39, 100680 Ploiesti, Romania; \\ ileghe2016@gmail.com \\ 2 Institute of Economics Agriculture, Volgina Str. 15, 11060 Belgrade, Serbia; jonel_s@iep.bg.ac.rs \\ 3 Faculty of Economic Sciences, Ovidius University of Constanța, Ion Vodă Street, No. 58, 900527 Constanta, \\ Romania; dumitru.nancu@gmail.com \\ * Correspondence: violeta.sima@gmail.com; Tel.: +40-723-547-210
}

Received: 31 March 2020; Accepted: 6 May 2020; Published: 14 May 2020

check for updates

\begin{abstract}
Automation and digitalization, as long-term evolutionary processes, cause significant effects, such as the transformation of occupations and job profiles, changes to employment forms, and a more significant role for the platform economy, generating challenges for social policy. This systematic literature review aims to provide an overview of the research to date related to influences of the Industry 4.0 Revolution on human capital development and consumer behavior. A search on the Web of Science identified 160 papers that met the inclusion criteria. The major objectives aimed to identify: the main types of influences of the Industry 4.0 Revolution on human capital development and consumer behavior; the main opportunities and challenges for new directions in education associated with shifting the work environment; and the drivers for human capital development and consumer behavior through the lenses of the Industry 4.0 Revolution. The results revealed some key aspects for the development of human capital: information, new jobs, the Internet, technology, training, education, new skills, automation, communication, innovativeness, professionals, productivity, artificial intelligence, digitalization, e-recruitment, and the Internet of Things, as well as the main drivers of consumer behavior: information, e-commerce, digitalization, the Internet of Things, e-distribution, technology, digitalization, automation, personalized, performance, artificial intelligence, behavior intention, e-shopping, and data mining.
\end{abstract}

Keywords: industry 4.0; automation; digitalization; artificial intelligence; information technology; communication technology; human capital development; labor market; customer behavior

\section{Introduction}

\subsection{Overview of Industrial Revolutions Through a Social Lens}

Technological progress has been the engine of the development of human society since the dawn of civilization. Over time, the concerns of the scholars in economics have evolved in parallel with the evolution of technology. So far, this evolution has been marked by four major leaps, known as industrial revolutions, generated by major inventions. These inventions are the steam engine, then electricity, digitalization, and using information technology, culminating in the significant advances made in the Information and Communications Technologies (ICT) field at the end of the 20th century, together with the advent and mass generalization of the Internet, which led to the fourth industrial revolution. 
In the field of manufacturing, the focus has shifted from increased production to increased productivity, then to automation, reaching connectivity, through the use of cyber-physical systems in production processes.

In the social field, the first industrial revolution (Industry 1.0) determined the evolution from the mercantile city, which grew based on the exchange of goods and products obtained from agriculture, to the industrial city, which grew based on increased productivity [1]. This transformation laid the foundations of the modern world, and by changing the social structure of human capital, the primordial importance of agriculture in the economic and social life has been taken over by industry. According to Frey and Osborne [2], people had a fear of technological unemployment. For this reason, several hundred years passed between the first knitting machine invented in 1589 by William Lee and the first industrial revolution. Moreover, this revolution led to the replacement of workers' skills by simplifying their tasks [3]. The workers took over the role of supervision, regulation, and control of the machines [4,5]. The second industrial revolution (Industry 2.0) brought the transition from the industrial city to the planned city. In the planned city, the new type of worker was exempted from the productive processes that involved gross physical labor, which has been replaced by social and security services, mechanical equipment, and total automation. The third industrial revolution (Industry 3.0) caused a transition from the planned city to the fragmented city, where industries were increasingly moving away from the markets, thus changing the economic systems and methods of production. In the fragmented city, a new economic-social order was born, separating, even more, the housing from the workplace, consumers, urban life, and research and innovation institutions. The fourth industrial revolution (Industry 4.0) brought about the transition from the fragmented city to the smart city [6]. At this current stage, the economic-social transformations do not have their roots in discovering a new form of energy, but they are based on the latest technological phenomenon-digitalization. The technology has made possible new products and services that have generated significant transformations in both personal and professional life, emphasizing the interaction between machines and people.

Tay, S. I. et al. have presented Industry 4.0 as a global change for each part of the company, through digitalization and automation, as well as through the manufacturing processes [7]. The concept of Industry 4.0 was easily and quickly accepted by the big international companies that already used techniques for the continuous improvement of the quality of processes and products and had high standards for research and development, to increase their competitiveness in the market [8]. The means of adopting this concept are self-optimization, self-knowledge, and self-personalization in the industry. In this way, workers communicate with computers rather than operate them, according to Tay, S. I. et al. [7].

\subsection{Industry 4.0 in Definitions}

Introduced in 2011 at the Exhibition in Hanover [9], the concept of Industry 4.0 has aroused the interest not only of producers but also of researchers. Thus, Kagermann et al. considered that the implementation of the concept of Industry 4.0 in the production sector implies the use to the maximum capacity of the power of communications technology and innovative inventions to stimulate the development of production technologies [10]. Quin et al. stated that Industry 4.0 could ensure the real development of companies by generating a reliable production environment. An important role is played by the intelligent data collection and interpretation, the correct decision making, and their timely implementation as a result of using the most advanced technologies, which allows faster data collection and interpretation procedures [11]. Schumacher et al. emphasized the network of advanced technologies in the value chain. Services, automation, robotics, artificial intelligence, the Internet of Things (IoT), and additive manufacturing are the elements that will reshape businesses in different industries. The new wave of transformations in production systems will blur the boundaries between the real world and virtual reality, causing the phenomenon of Cyber-Physical Production Systems (CPPS) [12]. In the Industry 4.0 scenario, the Cyber-Physical System contributes to the decentralization of the operational decision-making process by introducing autonomous machines, creating a modular 
structured intelligent factory [13]. Industry 4.0 aims to build open and intelligent manufacturing platforms for the application of information in industrial networks, bringing innovation in business models $[14,15]$. A smart manufacturing system needs more autonomy and sociality capabilities, as key factors of self-organized systems. Several features of Industry 4.0, namely, physical, digital, and biological worlds [16], significantly contribute to the improvement of the industrial environment, generating positive effects on governments' economies and development plans. Schwab emphasized that Industry 4.0 is one of the most important leaps in the global industry and economy [15]. Wang et al. have highlighted that Industry 4.0 makes full use of emerging technologies and rapid development of machines and tools to meet global challenges by improving industrial processes. The central concept of Industry 4.0 is the use of advanced information technology to implement IoT by integrating engineering knowledge [16]. The effects are on the production, consisting of increasing the speed of the processes, improving the efficiency of the production systems, and reducing the number of problems and the downtime, which ultimately leads to cost savings $[17,18]$. The results appear on the finished product, which has a higher level of quality and is more comfortable and cheaper to use and maintain. The concept of Industry 4.0 is an opportunity for development and competitiveness improvement [19]. Wyrwicka et al. have shown that moving to Industry 4.0 is an advantage to stay competitive in any industry. In this sense, modern machines and tools, which use sophisticated software and network sensors, can be used to plan, predict, adjust, and control business results, to lead to optimization of the value chain [20]. The result is a more dynamic production flow [21]. On the other hand, a significant negative effect is a disruption in job markets [22]. The complex and integrated development of science and technology corresponding to the stage of industry 4.0 will not only redesign commerce, culture, and society, but also our biology and ethics [23].

Schumacher et al. [12] synthesize the concept of Industry 4.0 as a mix of advanced technologies, which use the internet widely to support certain technologies. They use embedded systems, for integrating and combining intelligent machines with human actors, in manufacturing processes that require new types of technical data and generate high agility value chains.

Summarizing, the above definitions, several advantages of the industrial revolution 4.0 can be identified, namely: increasing economic efficiency, increasing labor productivity, flexibility and intelligence, reducing manufacturing costs, and increasing returns on investments. Regarding the increase of economic efficiency, it is noteworthy to modify the relation between human capital and ethnic capital, which is now automated. With less social capital and more technical capital, companies make decisions faster. The automation of the technical capital has resulted in high quality products and services. Increased labor productivity is primarily obtained since the downtime of the production lines has decreased, with decisions now being made automatically or semi-automatically. Production is monitored, and it is much easier to introduce new products on the manufacturing line and create opportunities for a single manufacturing operation. The production is flexible, and the factory is intelligent. Lower manufacturing costs and increased profitability result from the introduction of advanced technologies. Manufacturing costs will decrease significantly but over time. Initially, the investment costs of their implementation will be quite high, but they will be amortized over time. The benefits to the industry and the potential return on investments are what matter.

There are disadvantages to the Industrial 4.0 Revolution. The reduction of creativity can occur due to the automation of machines and the disappearance of human capital from the production technology. Human capital can generate controversy with its creativity, while devices are optimized, set up, and programmed to perform, despite the errors that may occur [23]. Increasing the unemployment rate, at least in some areas, can be another negative effect. Between the degree of production automation and the unemployment rate, there is a directly proportional relationship: the higher the degree of production automation, the higher the unemployment rate [23]. The automation of manufacturing technologies, and job computerization have dislocated much of the human capital, causing a new reconfiguration of it. On the other hand, however, the latest technologies will lead to the creation of new jobs, and there will be new production areas. The impact on environmental protection is also 
significant. Specific technologies and equipment that are incorporated in the production facilities of Industry 4.0 have a substantial effect on the environment. As a negative effect, data security breaches may occur. Internet of Things is an interrelational system of artificial intelligence, and companies are still working to fill the gaps in its security. The complexity of the tasks reduces its abilities. Although the production technologies of Industry 4.0 lead to an increase in product quality, they have not yet been able to solve the problem of sophisticated production. Human capital is currently the only type capable of carrying out complex, customized production tasks. Training with employees is required for new technologies. Apart from the maintenance provided to the production technologies of Industry 4.0, human capital must be trained in order to implement, operate, and maintain the automated systems properly and to ensure their continuous operation. The time frame for implementing Industry 4.0 is relatively large and requires efforts throughout industry. Initial costs are high.

\subsection{Human Capital in the Industry 4.0 stage}

The implementation of new technologies affects both employees operating in industries as well as organizations. The problem of the competence framework implies a three-dimensional approach, involving the level of the enterprise management, the fields of the production process and the types of competences [24]. According to Gan and Yusof, six types of effective Human Resources practices play essential roles in organizations, namely, knowledge management, HR policy making, training, recruiting, a reward system, and job design. They could improve the performance of organizations by equipping the workforce with up-to-date skills [25]. There is a need to identify the organizational strategies and their responses in adapting to the substitution of human workers by using robot and automation in this stage [26]. The Industry 4.0 Revolution is characterized by the decisive role of the efficiency of organizing the exchange of information. The structure of the technological mode of production has changed from the model: information + knowledge + innovation, corresponding to the knowledge economy, to the model: human intelligence + new information technologies + information + innovations, in the Industry 4.0 era. In this stage, the creativity of an individual, and the formation of human capital are the qualitative basis of the good. In the Industry 4.0 stage, it is necessary to adapt the education system to the new development requirements of the society; under these new conditions, only the knowledge gained will contribute to the development of Industry 4.0 and its safe development $[27,28]$. For Industry 4.0, depending on the industrial sector, specific skills and human tasks may be different from others, due to the divergence of processes. Some changes in terms of abilities and tasks have been observed [29]. Therefore, human capital will have significant participation in the work and will undergo a redirection of jobs and learning [30].

In the Industry 4.0 era, people are involved in the entire production system: as system designers, as workers, and as customers of manufactured goods. The requirements and needs of each individual involved in the process should be included in the system communicating needs and requirements amongst everyone involved [31].

\subsection{Marketing in the Industry 4.0 stage}

As the role of information and communication technologies in the purchasing process grows steadily, customer expectations also increase, forcing traders to react quickly to market movements [32,33]. Since the beginning of the Industry 4.0 era, researchers have predicted dramatic changes in the way of interaction between consumers and retailers, driven by the global use of new technologies and the imminent emergence of new efficient retail business models [34]. The integration of technology and the Internet has led to the emergence of connected customers [35]. They inform but also purchase, using a wide range of devices, such as smartphones, tablets, and laptops. This change has generated changes in the organization of marketing departments, which need to work integrated with IT and technology departments to expand consumer access to content. To remain competitive, marketers need to integrate these new devices into marketing campaigns and gain skills in using technology [36]. The use of technologies is becoming a source of key competencies and capabilities, 
generating sustainable competitive advantages for organizations. The use of ICT in business has also raised issues related to cybersecurity. With the emergence and spread of social networks and the use of mobile devices and related technologies, consumers are becoming more and more connected to each other and to organizations. In this new era of Industry 4.0, business models, in general, and marketing strategies, in particular, need specific innovation. Organizations and managers are looking for new ways to market products more efficiently, in an increasingly competitive environment [37].

\subsection{Objectives}

This demarche was performed aiming to understand the following issues:

- Identifying the main types of influences of Industry 4.0 revolution on human capital development and consumer behavior;

- Identifying the main opportunities and challenges for new directions in education required by shifting the work environment in the Industry 4.0 stage;

- Identifying the drivers for human capital development and consumer behavior in the context of the Industry 4.0 Revolution.

\section{Motivation}

The Industry 4.0 Revolution requires the Smart Manufacturing concept. In this new context, employee interactions with machines are defined. The interconnections created between the various actors represent defining elements of the new intelligent production systems, and the interfaces between workers and machines become key points. These characteristics require creative and inventive workers who are also endowed with expertise and skills to work in such environments. Their provider can only be an education system based on creativity, inventiveness, and knowledge [38]. In the context of Industry 4.0, human resources management faces new challenges of knowledge and skills related to new technologies and processes. To meet the needs of the present and future labor market, the development of the labor force requires the development of necessary skills. In Agolla's opinion [38], to effectively cope with the new challenges of the workplace, as defined by the Smart Manufacturing and Industry 4.0 Revolution, workers must develop specific competencies, abilities, skills, knowledge, and attitudes. They must become familiar with the technology of things (ToT), be capable of human-machine interactions, be able to access the technology-technology interfaces, proving that they possess a good understanding of the systems in the network, creativity, and innovation.

Boston Consulting Group (BCG) researchers have stated since 2015 that infrastructure and education must be adapted [39]. Manufacturers and suppliers need to consider their adaptation as they incorporate the technologies of Industry 4.0. Government, industry associations, and businesses should participate in this combined effort. The infrastructure must be fast, secure, and reliable enough for companies to be able use it for real-time data transmission. In the opinion of BCG scholars, the necessary improvements are aiming at fixed and mobile broadband services. Regarding education, BCG members stated that, on the one hand, school, training, and university programs need to be adapted and, on the other hand, entrepreneurial approaches must be strengthened, to increase the IT skills and innovation skills of the workforce. In a narrower sense, human capital management is gaining new meanings for corporate strategies. The intelligent manufacturing and Industry 4.0 Revolution involve the automation of processes, which leads to an increase in the number of workspaces with a high level of complexity, thereby requiring a high level of staff education [40].

The expectations of the industry as a result of its transition to the fourth phase of development justify EU's budgetary effort to implement the Industry 4.0 Agenda. The main benefits consist of increasing manufacturing efficiency by reducing the duration of the technological process, reducing the waste in the process chain, greater adaptability to the needs of customers, improving the quality of the products, and, finally, reducing the costs of manufactured products and reducing the waiting times for the final consumer. These led to the inclusion of the Industry 4.0 concept in the strategic 
development programs of some developed countries in world. Emerging economies must be an active part of this qualitative leap in industry.

The following considerations justify this analysis:

- Industry 4.0 has created new opportunities and threats that must be known and assessed to gain new competitive advantages;

- The competitive advantage of the cheap and skilled workforce is becoming increasingly visible and puts emerging economies in a deadlock on the future development model. To maintain economic growth, emerging economies need educational and training programs to develop skills, especially digital ones, which are increasingly demanded by the labor market.

\section{Materials and Methods}

A systematic literature review was conducted to provide an overview of the research to date related to influences of Industry 4.0 revolution on the human capital development and consumer behavior. This systematic literature review is based on Preferred Reporting Items for Systematic Reviews and Meta-Analyses (PRISMA) (http://prisma-statement.org/), being prepared following the points in the report for systematic reviews and meta-analyses [41,42].

Systematic Literature Review (SLR) is a method used to identify, evaluate, and synthesize the current situation of specific research topics in the specialized literature. This technique involves localization, restrictive collection, rigorous scientific methodological analysis, and eliminating the subjective element. The purpose of SLR is building an overview, adequately documented on a specific topic and providing a correct summary of the literature, resulting in an estimate of the overall effect for a study population [43]. The systematic review is becoming increasingly important in social science research. The scientific importance of SLR comes from its emphasis on systematically identifying and collecting all available information on a specific topic. Based on this information, it is possible to determine a certain tendency specific to the theme or domain studied. In a SLR targeting research in the field of social sciences, according to [44], the high degree of variability in the studies related to the social sciences area must be considered.

Our approach to conducting this review was based on Snyder's approach [45] and consisted of four stages: (1) designing the review, (2) conducting the review, (3) analysis, and (4) writing up the review.

\subsection{Information Source Search Strategy, and Identification}

A detailed strategy was developed for using the Web of Science database. A search for publications addressing Industry 4.0-related concepts, as well as human capital and consumer behavior, was conducted in February-March of 2020. The Web of Science database was selected due to its broad coverage. In addition, we performed a partial search of gray literature in Google Scholar. The last search in all databases was performed on March 2, 2020.

Regarding the search for information in articles, we have included only the open access sources because of budgetary constraints. In the first search, including articles that are not open access, 2204 titles were provided. Only 762 were maintained in the analysis, satisfying the open-access condition. This could be a limitation of the research.

Figure 1 shows the initial search yielded a total of 762 records; however, 355 records were excluded due to their document type and language. We excluded conference proceedings, book series, books, and other publications. Only journal articles were included in the systematic literature review, aiming at high-quality studies ensured by the peer-review process undertaken by academic journals. Additionally, we excluded articles written in other languages than English, thus eliminating 27 records in various other languages. Besides that, we considered only open access articles, considering the necessity of studying the entire articles. The excluded publications were organized by criterion of exclusion. 
The reasons for exclusion were:

- Not journal articles

- Other languages than English;

- Not open access papers;

- Studies not focusing on socio-economic aspects;

- Conceptual articles without evidence of a serious concern involving human capital or consumer behavior.

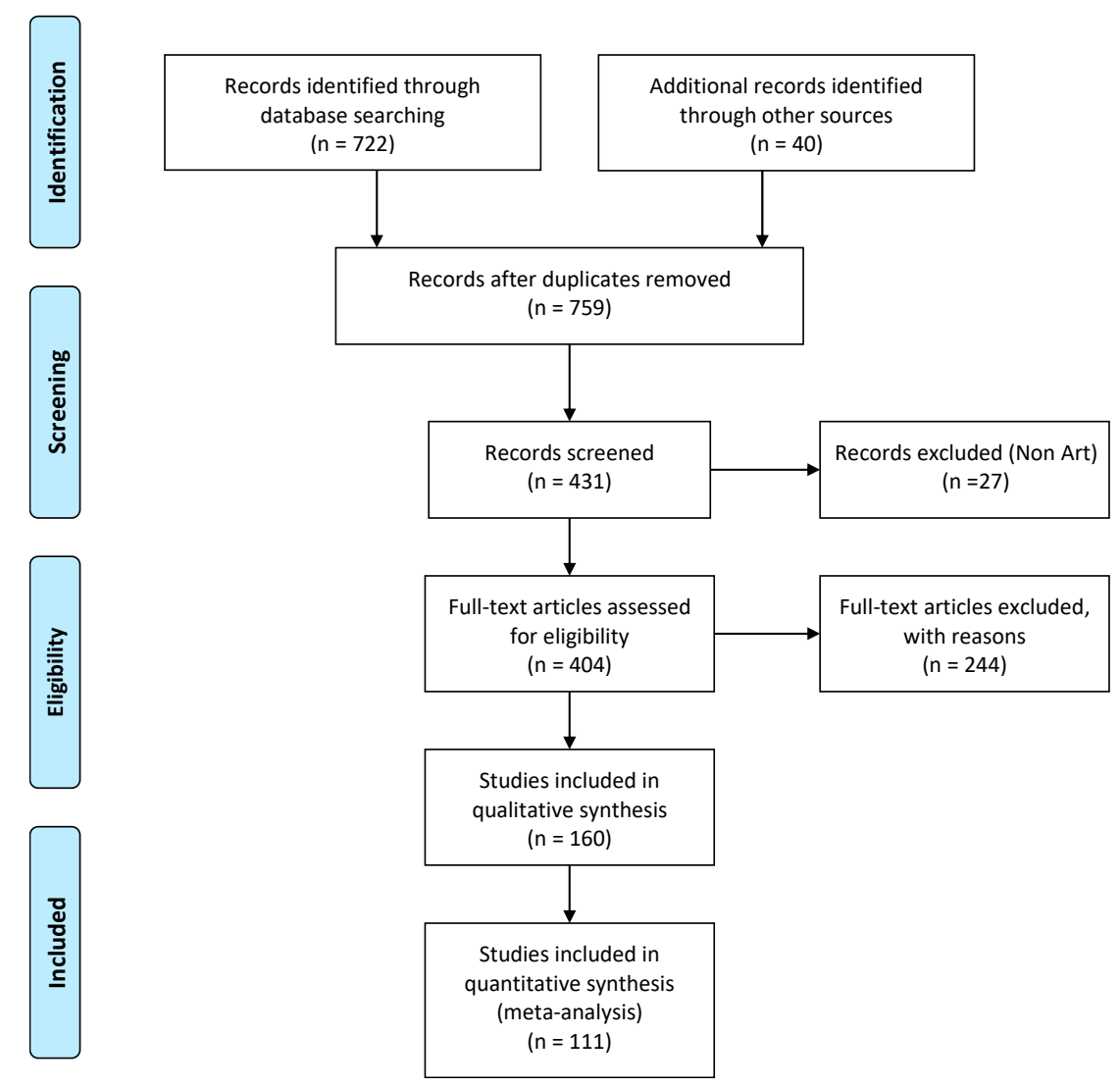

Figure 1. Flowchart of search and selection criteria. Source: Authors own design based on PRISMA.

\subsection{Inclusion and Exclusion Criteria}

The following combination of terms used to search references using Boolean operators was performed:

$\mathrm{TI}=$ (Industry 4.0* OR Industry 4.0 Revolution* OR Industrial Internet of Things* OR Internet of Things* OR Digitalization* OR Cyber-Physical Production Systems* OR Automation* OR Information Technology* OR Artificial Intelligence* OR Communication Technology*)

TS $=\left(\right.$ Human Capital Development ${ }^{*}$ OR Human Resources* OR Labor market ${ }^{*}$ OR Labor market ${ }^{*}$ OR Consumer Behavior* OR Consumer Behavior*).

Figure 1 shows in detail the inclusion and exclusion criteria. The inclusion and exclusion process were prepared in accordance with the items of the PRISMA flow diagram and the Checklist. In the qualitative analysis, first, we screened the abstracts; 49 records were excluded because they provided no approach of the related to Influences of Industry 4.0 Revolution on the Human Capital Development and Consumer Behavior. Posteriorly, we proceeded to read the articles. 


\section{Results}

A total of 762 articles were initially found as a result of the database interrogation. After duplicate removal, and exclusion criteria application, 160 titles and abstracts of articles were selected and read. After reading the abstracts, 111 full-text articles were analyzed in detail, meeting the eligibility criteria.

\subsection{General Characteristics of the Studies}

The research methodology imposed a year restriction, requesting only publication since 2011, having in sight that industry 4.0 concept was introduced in 2011. Figure 2 displays the evolution of the number of selected published articles. If during 2011-2015, the number of publications increased relatively slowly and linearly, the pace then increased sharply, with a peak in 2018. This finding suggests that the impact of information and communication technology or digitalization or automation constitutes a growing research area.

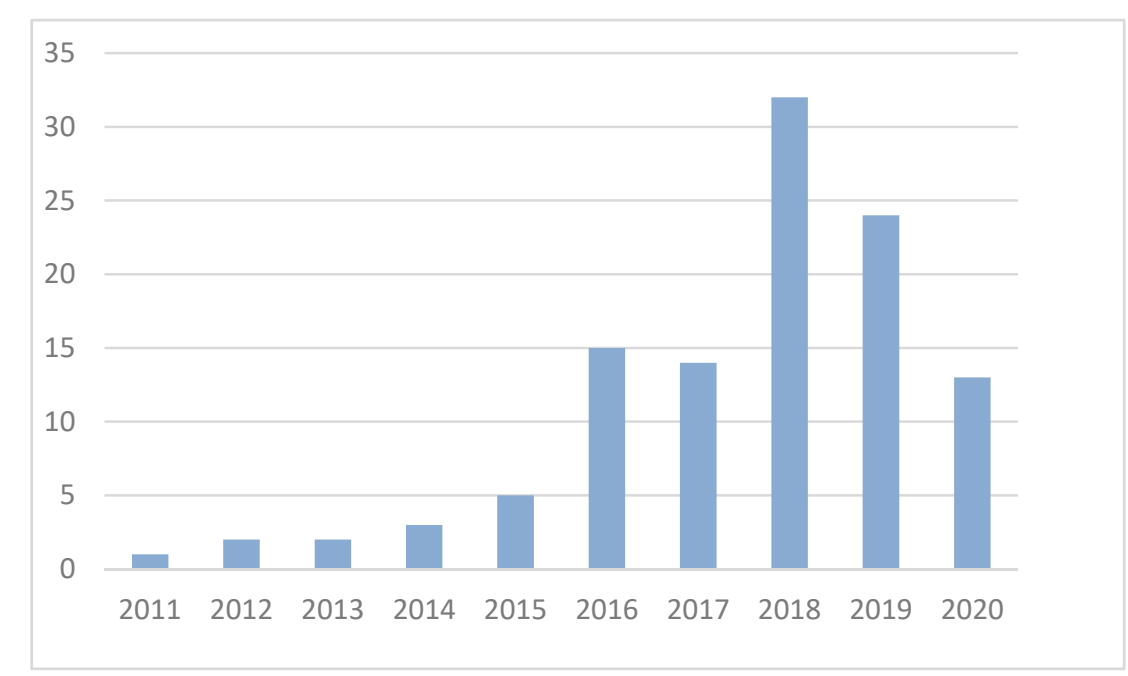

Figure 2. Number of selected published articles, per year. Source: Authors computations, based on literature surveyed.

The UK plays a leading role in the research on Industry 4.0 or related concepts and their influences on human capital or consumer behavior or management strategies and marketing practices, with a total of $25(22.5 \%)$ publications, followed by the USA and Germany with $19(17.1 \%)$ and 14 (13.5\%) publications, respectively. A total of 23 (without Russia) countries were accounted for in the selected articles, encompassing applications mainly in Europe (76 studies corresponding to 25 publications and 13 countries). Of the 25 European publications, the most numerous are in Northern Europe, namely 10 , of which 8 in the UK, where most articles have been published. It is interesting to stress that the main publication source of papers has been Western Europe, namely in Switzerland. The countries of Eastern Europe are also well represented, with a total number of 6 publications, of which 4 belong to Poland.

The first published study on Industry 4.0 [46] was from Ukraine in 2012, following the first mention of the concept in 2011 [9].

The distribution of publications by country is presented in Figure 3. 


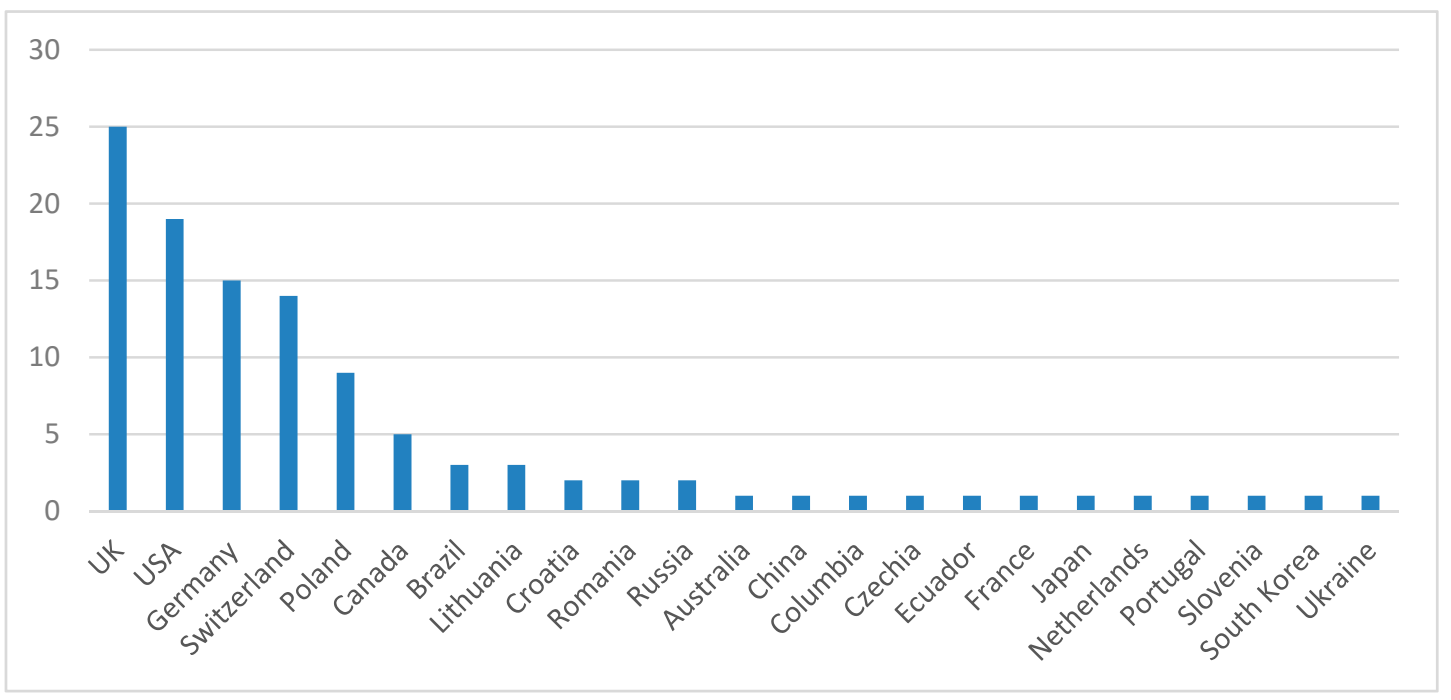

Figure 3. Number of selected published articles, by countries. Source: Authors computations, based on literature surveyed.

\subsection{Main Topics Highlighted in the Literature Surveyed}

Along with the topics identified by Büchi et al. [47], from the analysis carried out on the 111 articles, in our opinion, another topic can be noted, namely, marketing in the digital age. Table 1 synthesizes these twelve primary topics, which are described below.

- The phenomenon's diffusion: These changes are evident in the structure of stock exchanges, where the financial services industry wins first place $[48,49]$. The industrial structure of the stock indices no longer corresponds to the GDP structure, suggesting that the stock market does not reflect the economy. As a result of the growth of financial services, a new phenomenon has emerged-financing the economy and, in particular, the markets. However, significant changes in the industrial structures of GDP and stock markets are expected. The new economy is associated with new technologies. The share of GDP of traditional industries will decrease, and the percentage of GDP of robotic industries using IT will increase. These lead to the assumption that the financial services sector, which is particularly demanding for human capital, will show a downward trend in its role [50]. The transition to new technologies has to be made gradually based on national strategies. Governments need to consider a gradual change to economic and social systems based on new technologies. Problems that may arise are related to IT security, but also to the loss of many jobs [51,52].

- The impact of enabling technologies on the global economy, measured through productivity, employment and unemployment, and technological or legal changes: Digitalization will cause significant changes in the social-economic environment, but especially in terms of employment. Empirical evidence [53-55] does not show that this will generate mass unemployment. On the contrary, employment levels show remarkably robust developments in terms of both the number of employees and the hours worked. New jobs will replace traditional roles, and new business models will appear. Digitalization, as a long-term evolutionary process, has major effects, such as transformation of occupations and job profiles, changes in forms of employment, a greater role for the so-called platform economy, generating challenges for social policy [56-58]. New and emerging technologies led to the automation of jobs and the rise of entrepreneurship, causing radical transformations on labor markets [59]. The information technologies determine qualitative changes in the educational services, creating conditions for improving life and increasing the comfort level of the inhabitants, both individually and at the community level [60]. In this regard, the development of information technology can contribute to the personalized choice of the profession in the social, educational, and communications environment of a smart city. Its facilities 
provide the opportunity to combine the stages of specialized training based on the needs of an individual, economic, and social development, the demands of the labor market in the city, community, or region, and the systematic aspirations of the corresponding communities [61,62]. The implementation of advances in science and technology has significantly affected not only the increase in labor productivity and economic growth. Still, it has also brought about changes in industrial structures [46,63-65]. The implementation of artificial intelligence in production systems generates, besides beneficial effects, ethical, and legal problems [66]. Labor legislation must adapt to dealing with the changes imposed by Industrial 4.0 revolution [67-69]. A reorganization of the production process is required [70,71].

- Innovation in business models: Industry 4.0 affects manufacturing industries differently. An increase in personnel costs affects the machine and plant engineering sector. After years of concern for equipment development and production, interest has shifted to software. The workforce must be qualified to adapt to the effects of IoT introduction, as a result of transforming the role of employees from being operators to being problem solvers. Industry 4.0 changes business models across different manufacturing industries. Companies are willing to support higher education institutions by investing in interdisciplinary education in the areas of economics, engineering, computer science, and mathematics for future employees. The electrical engineering and ICT sectors not only address their customers but also their customers' clients as well. Thus, "B2B2C" type relationships are developed. On the other hand, some industries are experiencing slight changes. Here we are talking about sectors that incorporate high-level technologies, such as the medical engineering sector or the automotive sector [72]. Along with Industry 4.0, servitization also contributes to the transformation of companies, focusing mainly on adding value for the customer [73]. Creating value by integrating design contributes to increasing the competitiveness of firms through innovation [74,75]. This approach allows them to acquire uniqueness, facilitating their fight against competitors, who will find it harder to imitate their business model and strategy. Companies thus acquire intelligent and sustainable competitive power [76]. Changing management approaches it is necessary to support innovative solutions [77,78]. In order to contribute to the creation of sustainable industrial values, the Industrial Internet of Things (IIoT) requires an extension of the perspective of creating the sustainable value of the Triple Bottom Line (TBL). From the economic, ecological, social, and technical dimensions, it must be supplemented with three other dimensions, namely technical integration, data and information, and public context [79]. Currently, the effects of IIoT at the business level are underestimated or too little considered, even if the companies validate their existing business model in this context [80]. SMEs play an essential role in creating industrial value. They have imposed a business model that aims to create value, capture value and offer value. The Industry 4.0 revolution affects this model, acting on three levels, namely, high-quality process digitalization, intelligent manufacturing, and connectivity between companies. The SMEs' business models also differ according to their relation with Industry 4.0: craft manufacturers, preliminary stage planners, Industry 4.0 users, and full-scale adopters [81]. Artificial Intelligence (AI) is being applied in many sectors, allowing a broad range of innovative solutions. Specific AI business models are developing, meaning companies face new challenges from regulation to human resources and data collection. Managing AI-based innovation led to increased demand for AI experts, but also for clear rules. Policies to support AI-based innovation, therefore, should focus on human aspects [82].

- Improving the value chain: Transition to Industry 4.0 means growing expectations, especially for companies that have a modern IT infrastructure. That allow all operations within an organization to be linked through computer systems and network information management. These lead to greater efficiency in the manufacturing flow and develop self-learning intelligence by taking advantage of the specific Industry 4.0 infrastructure. At the level of fully integrated production systems, "intelligent" machines and products will be able to communicate with each other. The challenge will be to find the human talents that possess specific knowledge and skills to develop 
the analytical algorithms needed to implement these processes. A new type of human-machine relationship will replace the classic relationships between suppliers, companies, and customers. The machine-machine and human-machine interactions will allow for more flexible production and production customization, leading to smaller batches. In this way, companies can respond to the pressure of technological progress at the customer level, which generates customers with special needs, imposing personalized product designs [83]. It is essential that the system designers take into account the requirements and needs specific to the human factor. A particular process of mediation should act as a facilitator in this regard, creating ownership in the acceptance system and allowing a company to actively influence and control the design and use of the Industry 4.0 concept [31,84].

- Redefining the supply chain: The supply chain plays an essential role in the Industry 4.0 stage. Thus, companies have several types of distribution channels available to reach customers. They can use multi-channel, cross-channel, over-the-counter, or online commerce. Also, digitalization and accessibility to just-in-time information allow manufacturers and distributors to respond more quickly to any new issues emerging in the market and better manage their spending [85]. In the supply chain oriented to the Industry 4.0 scenario, profound changes occur, such as real-time visibility across the entire supply chain, a continuous collaboration between the chain stages. The consumer is much more involved. He wants an immediate reaction and exchange of information. He is waiting for online order confirmation, tracking an order status, or updating information on shipping and order delivery. A particularly noteworthy area is data availability, more precisely, the solutions that allow real-time tracking of operations and the avoidance of unwanted events [86]. Digitalization will completely change the business environment and organizational culture of companies. New structures of the market will emerge, customer behavior will be different, with them being much more involved in the act of buying and selling. Process automation will improve the decision-making process in organizations because the emotional factor specific to people will be eliminated. The digitalization will cause a transition from homo economicus to homo cyberneticus [87]. Scientists and practitioners aimed to understand the conceptual transformation of the supply chain under the influence of digitalization. Studies $[88,89]$ have shown the need to consider the following issues: (1) current trends and requirements of the supply chain management; (2) digitalization effects on the classic management model.

- Product reconfigurations: Digitalization will transform classic products into intelligent products. Smart products will have new competitive advantages in the market. The intelligent product becomes a complex system that combines hardware, sensors, data storage, microprocessors, software, and connectivity in numerous ways. They add to the physical component of the classic product, an intelligent component, and a connectivity component, which gives them the qualities of being smart and connected, triggering a new era of competition $[90,91]$. The context is favorable to large companies, which have resources for implementing new technologies, not only in the production process but also in communication and product promotion. IoT, which will significantly influence people's behavior, will also affect the decision-making model at different stages of the buying process [92].

- New human resources competencies and skills: The labor market has undergone remarkable changes in the context of technological changes. Industry 4.0 is especially beneficial in highly developed countries, which gain a new competitive advantage, but it also causes unemployment because of high levels of automation [93]. New jobs have emerged that require new competencies and prospective skills. The educational profile of human capital is changing, and new approaches to education systems are emerging [94,95]. Human capital is transitioning from the paradigm of an initial qualification sufficient for a whole career to that of a continuous accumulation of new knowledge and skills, through periodic training once every few years. These must be correlated with the development of new personal skills related to management, risk management, leadership, self-organization, communication skills, or emotional intelligence [96,97]. Emerging technologies 
make it possible to divide the classic work tasks in support of global and digital production, allowing the generation of new employment models, namely, part-time, temporary, on-demand, etc. These have advantages for certain categories of workers, (i.e., the best trained, usually younger), offering flexibility for them. They are often the beneficiaries of online recruitment platforms. Women can, in turn, become beneficiaries of the increase in the degree of digitalization, allowing them access in areas that until now, were prohibited or in which they were less represented. On the other hand, those with a low educational level and belong to disadvantaged social classes, seem to register higher degrees of risk and social insecurity [96-98]. In high-tech industries, such as the auto industry, strategies for using human capital are less dependent on process technologies themselves. Studies [99] support the importance of factors at the workplace for the relationship between automation and skills, highlighting the role of the factory in the value chain and the international division of labor. There is an important role for the institutional framework, but also for the image that a company has in the market [100].

- Developing communications between people, industrial components (equipment and machinery), and products and extending internal and external networks: In developed countries, digitalization will make the transition from organizational culture to cybersecurity culture much faster. For the development of this new type of culture, education, and research, public-private partnerships or international cooperation play essential roles [101]. The technical and technological progress has also led to the growth of high-quality products and affordable prices, requiring manufacturers to take measures consisting of the implementation of production technologies based on automation and connectivity, data, and security solutions. These require specialized personnel which are trained by the labor force providers able to generate the new skills needed to eliminate the existing skills gaps. These efforts create long-term effects, allowing businesses to maximize their profitability, leading to long-term success in improving productivity and reducing waste [102]. In a global and highly competitive market, characterized by an increasingly dynamic state, this could mean the difference between sustainability and irrelevance. Large companies have a higher capacity for innovation than SMEs. For this reason, it is essential to stimulate innovation capacity among SMEs. This can be achieved by introducing strategic planning at the level of SMEs, in conjunction with a national strategic plan [103]. The current economic activity also addresses practices that are not sustainable in the use of resources. The industrial field undergoes a paradigm shift, which will determine radical changes in production systems and the relationships between it, the use of resources, and the environment. The production systems will evolve from centralized control to decentralized control, built on the self-regulating capacity of production. From this point of view, the essence of the Industry 4.0 concept is the introduction of intelligent systems capable of self-regulation. The human, technical, and production systems will communicate with each other, being interconnected, which requires the efficient functioning of logistical processes [104]. Online recruitment platforms allow better matching between the needs of the employers and the skills of the applicants to find suitable people for certain managerial functions [105-107]. IT's influences on communication are also generating implications for marketing managers dealing with increasingly demanded consumers in today's digital environment [108].

- Sustainability: The "post-economy of artificial intelligence" is characterized by the priority of new energy sources and social communication technology. It constitutes a new economic base, which makes the transition from the "economy of deficiency" to the "economy of abundance", which involves new architectures of social order. In the economy of artificial intelligence, new complex forms appear, which will create new pressures on market institutions involving competition, innovation, and commercialization [109]. Despite the difficulties facing the developing regions of the world, the changes generated by technology have created new opportunities to address the poor management of resources and to improve human well-being [110]. The Industrial Internet of Things (IIoT) is providing economic, ecological, and social benefits for industrial factories, including sustainability benefits involving the TBL. Kiel et al. [79] developed a framework for 
IIoT, extending the TBL with three dimensions called: "Data and information" referring to data processing and analysis capabilities, "Public context" describing requirements in terms of legal framework and standardization, and "Technical integration", referring to intra-and inter-company implementation of the IIoT. Some studies have highlighted geographical differences. Thus, SMEs in Germany are expected to have a smaller impact as a result of moving to Industry 4.0, considering it to be more of a challenge. In contrast, Chinese SMEs primarily see social benefits of this process [111]. The implementation of Industry 4.0 within SMEs also generates economic, ecological, technical, and social risks, the latter consisting mainly of job losses. As far as social risks are concerned, they can be controlled by re-qualifying human capital. As for the technical risks, they are mainly related to IT security and political risks. All these types of risks require a new kind of management, namely, an intelligent, synergistic, and predictive management, which is able to anticipate and manage all threats [112]. The use of new skills in information and communication technology contributes to the improvement of the functional management system [113]. Through the complex nature of digitalization and collaborative consumption, they generate new challenges for human behavior and social and business practices [114,115]. By using the latest technologies for teaching and learning, it is possible to develop the future qualified human resources needed for sustainable behavior [116]. The "post-economy of artificial intelligence" is characterized by the priority of new energy sources and social communication technology. It constitutes a new economic base, which makes the transition from the "economy of deficiency" to the "economy of abundance", which involves new architectures of social order. In the economy of artificial intelligence, new complex forms appear, which will create new competition, innovation, and commercialization pressures for market institutions [117,118]. According to Scavarda et al. [119], the global movement around themes like sustainability with the triple bottom line and Industry 4.0 allows for the establishment of a ground of connection with corporate responsibility towards society.

- Transforming internationalization processes: To be able to cope with the increasing competition in the international market, companies must innovate and internationalize at the same time. Given this context, the studies identified Industry 4.0 technologies that have the potential to increase the competitiveness of companies, namely, automation manufacturing, automation, distribution robots, self-driving vehicles, automation warehousing, digitalization, digital lean, digital reality, social media, flexibility, and horizontal and vertical integration [120]. Integration of IT resources, related human resources and communication between partner companies improve the firms' ability to manage international relations more effectively through shared control, interfirm coordination, cross-firm formalization, and hybrid centralization. These benefits increase business performance and IT capabilities help reduce potential contextual limitations and risks. Firms in international alliances should consider effective development of interfirm IT capabilities in terms of readiness of hardware and software, human resources, and organizational resources [121]. According to Strange et al. [122], the implementation of Industry 4.0 creates cyber-risks and implications for the privacy of individuals, and hence, the need for regulation. Online shopping is a global phenomenon, showing significant annual growth rates. However, buyers feel a lack of confidence, especially in the case of international purchases [123].

- Performance: Some studies show that in emerging economies, there are differences between how the adoption of different technologies of Industry 4.0 is associated with expected benefits for the product, operations, and aspects of side effects. Thus, in the case of companies focusing on differentiation, the beneficial effects appear after the implementation of product development technologies. Instead, companies that focus on reducing costs or on increasing productivity or operational flexibility should give priority to those Industry 4.0 technologies that make a significant contribution to improving the manufacturing process [124]. The large-scale transition to Industry 4.0 requires a systematic implementation of Cyber-Physical systems (CPS), which are the only ones capable of monitoring and synchronizing all information at all levels [125]. In addition, 
using computer algorithms, machines connected to the network will be able to work more efficiently, collaboratively, and resiliently [126]. According to Misztal et al. [127], an increasing quality and efficiency requirements as a result of production automation lead to organizational, technical and ergonomic implications. To achieve better business performance, managers must not neglect HRM activities [128,129]. The use of information technology, communication, and internet facilities contributes to increasing the efficiency of the health systems, offering new facilities, such as telemedicine, and allowing the increase of the population's access to high-quality services [130-134].

- Marketing in the digital age: Automation is everywhere, at home, in industry and, of course, in marketing and in retail. Marketing efforts focus on attracting, converting, and retaining. Automation used for attracting customers is aiming for increased online information traffic. With the evolution of the Internet, websites have started to be an essential tool for marketing. Over the past 25 years, the importance of using the Internet has increased. The marketing in the new Industrial 4.0 revolution focuses on building filtered messages through the information we hold about consumers and on the mass customization component. The companies that will give increased importance to customizing the products as unique as possible for their clients will be the ones that will have to win the market competition $[135,136]$. The Internet of Things has changed the way of information dissemination by changing customer behavior. Thus, the consumer experience can be improved with the help of data mining technology. The advantages result from the creation of customer and supplier networks, focused on the consumer, and supported by the Internet of Things, big data analysis, and relational fusion technologies [137]. It is necessary to track what is the consumer profile, to whom we address, what are his interests, from what sources does he get information, if he uses or not mobile devices, where he is when he comes in contact with the message, or what occupation he has, to understand users' acceptance and willingness of use for a store app [138-140]. The changes in the economic and social environment confront retailers with significant pressures, requiring them to apply new price optimization models to improve their incomes, margins, and market share. The novelty of these models resulted from three important changes: (1) Data; (2) Analyses; and (3) Automation [141]. In the future, artificial intelligence will substantially change both marketing strategies and customer behaviors [142]. Another important aspect is data security [143]: Are consumers willing to pay for improved security?

Table 1. Main topics of the included studies. Source: Authors based on literature surveyed.

\begin{tabular}{|c|c|c|c|}
\hline No. & Reference & Year & Topics \\
\hline 1 & {$[50,51]$} & 2018 & The phenomenon's diffusion \\
\hline \multirow{10}{*}{2} & [9] & 2011 & \multirow{10}{*}{$\begin{array}{l}\text { The impact of enabling technologies on } \\
\text { the global economy, measured through } \\
\text { productivity, employment and } \\
\text { unemployment, and technological or } \\
\text { legal changes }\end{array}$} \\
\hline & [46] & 2012 & \\
\hline & {$[10,63]$} & 2013 & \\
\hline & [70] & 2014 & \\
\hline & [53] & 2015 & \\
\hline & {$[56,65]$} & 2016 & \\
\hline & {$[20,59,83]$} & 2017 & \\
\hline & {$[7,57,61,64,67,68,71]$} & 2018 & \\
\hline & {$[52,54,60,69]$} & 2019 & \\
\hline & {$[55,58,66]$} & 2020 & \\
\hline
\end{tabular}


Table 1. Cont.

\begin{tabular}{|c|c|c|c|}
\hline No. & Reference & Year & Topics \\
\hline \multirow{5}{*}{3} & {$[12,72,80]$} & 2016 & \multirow{5}{*}{ Innovation in business models } \\
\hline & {$[15,79]$} & 2017 & \\
\hline & {$[74,75,77,78,111]$} & 2018 & \\
\hline & {$[73,76,82]$} & 2019 & \\
\hline & {$[62]$} & 2020 & \\
\hline \multirow{4}{*}{4} & [81] & 2016 & \multirow{4}{*}{ Improving the value chain } \\
\hline & [31] & 2017 & \\
\hline & [83] & 2018 & \\
\hline & [84] & 2019 & \\
\hline \multirow{3}{*}{5} & [87] & 2017 & \multirow{3}{*}{ Redefining the supply chain } \\
\hline & [85] & 2018 & \\
\hline & {$[86,88,89]$} & 2019 & \\
\hline \multirow{4}{*}{6} & [90] & 2014 & \multirow{4}{*}{ Product reconfigurations } \\
\hline & {$[11,16,92]$} & 2016 & \\
\hline & [8] & 2017 & \\
\hline & [91] & 2018 & \\
\hline \multirow{5}{*}{7} & [40] & 2016 & \multirow{5}{*}{$\begin{array}{l}\text { New human resources competencies } \\
\text { and skills }\end{array}$} \\
\hline & {$[59,79,96,97,99]$} & 2017 & \\
\hline & {$[5,38,93,98]$} & 2018 & \\
\hline & {$[94,100,102]$} & 2019 & \\
\hline & {$[95,106]$} & 2020 & \\
\hline \multirow{5}{*}{8} & [101] & 2015 & \multirow{5}{*}{$\begin{array}{l}\text { Developing communications between } \\
\text { people, industrial components } \\
\text { (equipment and machinery), and } \\
\text { products as well as extending internal } \\
\text { and external networks }\end{array}$} \\
\hline & {$[104,108]$} & 2016 & \\
\hline & {$[103,113]$} & 2018 & \\
\hline & [105] & 2019 & \\
\hline & [107] & 2020 & \\
\hline \multirow{4}{*}{9} & [110] & 2014 & \multirow{4}{*}{ Sustainability } \\
\hline & [79] & 2017 & \\
\hline & {$[111,114,116,117]$} & 2018 & \\
\hline & {$[112,115,118,119]$} & 2019 & \\
\hline \multirow{3}{*}{10} & [109] & 2017 & \multirow{3}{*}{$\begin{array}{l}\text { Transforming internationalization } \\
\text { processes }\end{array}$} \\
\hline & {$[121,122]$} & 2018 & \\
\hline & [120] & 2020 & \\
\hline
\end{tabular}


Table 1. Cont.

\begin{tabular}{|c|c|c|c|}
\hline No. & Reference & Year & Topics \\
\hline \multirow{6}{*}{11} & [123] & 2012 & \multirow{6}{*}{ Performance } \\
\hline & [130] & 2015 & \\
\hline & {$[38,126,127]$} & 2016 & \\
\hline & {$[125,128,131]$} & 2017 & \\
\hline & [129] & 2018 & \\
\hline & {$[124,134]$} & 2019 & \\
\hline \multirow{5}{*}{12} & {$[132,133,144]$} & 2016 & \multirow{5}{*}{ Marketing in the digital age } \\
\hline & [135] & 2017 & \\
\hline & [138] & 2018 & \\
\hline & {$[140,141]$} & 2019 & \\
\hline & [139] & 2020 & \\
\hline
\end{tabular}

Table 1 displays the main topics of the included studies. Looking at this through time lenses, it was found that certain issues have aroused more interest in different periods. The topic of performance was mainly addressed in 2015-2016. New human resources competencies and skills received the attention of researchers in 2017. Interest has shifted to the innovation in business models and the impact of enabling technologies on the global economy, measured through productivity, employment and unemployment, and technological or legal changes. Sustainability came first in 2019. Marketing in the digital age has become the focus of interest in 2020.

\subsection{Main Types of Influences of Industry 4.0 Revolution in Human Capital Development}

Given the noticeable and quick transformation and the increased reliance on modern technology [57], the question which arises is how all these are changing work, employment, methods, approaches, and processes related to human resources management field in today's corporations.

Automation and robotization of production processes will mainly affect the sectors of workers whose work is repetitive and routine, leading to the loss of many jobs, mainly affecting employees with lower education. According to many scholars [51], workers will have to acquire a different or completely new set of skills to cope with these transformations in production processes. This can help increase employment, but at the same time, it will alienate a large sector of the workforce.

Among all the transformations that Industry 4.0 brings in industrial processes, digitalization is the area that seems to affect the entire economic and social environment on the broadest scale. At the level of the labor market, it requires a new set of skills needed to meet the requirements of emerging types of work (such as platform work), as well as imposing new approaches, especially in higher education. On the other hand, at the level of higher education, as a result of the intensification of the competition following globalization and market opening, another new trend appears, namely its commercialization. The way to solve these problems involves rethinking of traditional learning methods [58].

Wyrwicka and Mrugalska [20] have shown that there is a shortage of ICT professionals in European labor markets. This lack of employees is mainly manifested in the advanced manufacturing sectors, where analysis of big data and cybersecurity are needed. At present, although various actions have been taken to stimulate the acquisition of e-skills, especially in developed countries, the younger generation does not seem particularly interested in digitalizing the workplace or working in ICT, despite the fact that they perceive this sector as being the most advantageous one.

Human capital is the key resource needed to support the efficient use of IT. The pace of technological innovation has very high values, and workplaces are changing faster than ever, while acquiring new skills has become far more important than having the right credentials, which creates new pressures 
both on labor market and educational systems. Thus, even people who know how to use and operate technology are required to renew and expand their skills and competencies. Therefore, the key seems to be to the education system, which must find new resources and methods to meet these challenges. Educated workers not only have the skills to use new devices, but they are more flexible, and can adapt more easily to the introduction of new technologies. Some studies have found a strong association between the level of education and IT investments [145]. These results support the hypothesis that the effects of IT on productivity are more significant in countries with high levels of education. At the same time, the role of policies to increase tertiary education is highlighted.

To increase the pace of acquisition of new skills by employees and future employees, decision-makers should consider creating IT "clusters" in places such as schools, libraries, or community centers. These could be able to provide IT packages, infrastructure, and training for users. Such integrated efforts can have more significant effects on IT productivity than a simple distribution of devices such as laptops or mobile phones in developing regions [63].

The increasing use of software, connectivity and analytics will increase the demand for employees with specific skills. Therefore, the need for skilled workers in the development of software and IT technologies will increase. This skills transformation is also a key challenge for workforce providers. To respond as adequately as possible to these challenges, a combined effort from all social actors is needed, namely the government, schools and universities, trainers, but also companies. They need to work together to adapt the curricula and to strengthen the entrepreneurial approaches increasing the IT skills and innovation skills of the workforce [39].

To understand the notions and concepts of other disciplines, they must be flexible, open to change, and have the ability to work in interdisciplinary teams. The ability to communicate, having cultural openness, and the ability to use virtual tools are essential for this.

To successfully cope with these changes, people should first develop skills such as creativity, experimentation, situational assessment, design, organization, and, last but not least, reengineering. The use of electronic means and big data tools are mandatory skills for the 4.0 engineer, who must be able to process and analyze large amounts of data from multiple sources, assess the validity of the information and its credibility, and draw relevant conclusions [20].

Agolla [38] argued that as Industry 4.0 is implemented on an ever-increasing scale, both nations and organizations need to engage in education systems that focus on knowledge beyond what is currently taught. This approach may require abandoning traditional education systems and stimulating the creativity of children from an early age to university, by focusing on learning outcomes that encourage the three components of creativity, namely, creative thinking, expertise and cognitive skills. The Industry 4.0 revolution entails a revolution in education, aiming to produce human capital capable of benefiting from the needs of the Industry 4.0 revolution for Smart Manufacturing's competitiveness.

Studying situation in EU countries, Lovric showed that education, especially at higher levels, is the critical factor in increasing the productivity of developing countries, contributing more than the implementation of ICT [46]. A high contribution to the development of human capital has a high enrollment rate in tertiary school. It turns out that education is a critical factor that must be taken into account by decision-makers to achieve positive effects on increasing productivity. The suggestion that emerges is the introduction of IT technology at an early age in schools, the development of complementary training programs, and the organization of tertiary programs for skills development.

A clear conclusion is that new educational systems must be introduced. However, this does not seem to be able to solve the problem of older workers, as Sung showed [51].

Regarding recruitment methods, promoting new jobs correctly and efficiently becomes essential. In this sense, the analyzed studies explain the importance of developing an advertising profile for Industry 4.0 jobs [107]. Technology can help achieve these goals by using data mining techniques to collect relevant information about the knowledge and skills needed in fast-changing industries. In such analyses, the extracted job profiles indicate that organizations are not looking for traditionally educated workers, but creative experts, with multidisciplinary skills, who really can contribute to 
increasing the performance and competitiveness of companies. These analyses can contribute to the development of human capital, helping, on the one hand, the labor force and, on the other hand, human resources professionals and labor providers, i.e., education systems. Thus, for the first category, typologies of the job profiles required in Industry 4.0 can be developed. For the second one, new ways can be identified for how to track changes in the knowledge and skills needed in Industry 4.0. For the third category, updated information on necessary changes in curricula may be provided. Last but not least, recruitment companies can benefit from exploratory analyses of job advertisements.

One of the analyzed studies [38] pointed out that the use of social platforms is a current and interesting topic both in human resource management and in marketing.

\subsection{Main Types of Influences of Industry 4.0 Revolution in Consumer Behavior}

Industry 4.0 will bring new benefits to customers as a result of the introduction of new technologies. As the degree of technological complexity increases, the demands of the requirements will increase, and clients with individual or even unique needs will appear. Therefore, new purchasing methods may emerge [63]. Customers can have individual requests, they can request specific functions of, or even they can purchase a single product. Customers can change their order and ideas at any time during production, even at the last minute, without being charged any fees.

In Industry 4.0 specific interconnected networks, manufacturers have to collect and analyze a massive amount of data. As a result, the issue of privacy arises as a concern for both customers and manufacturers [51,92]. This issue, which could pose a threat to privacy, will be a challenge for both parties.

People are willing to pay for improved security. The presence of security information can influence consumers and therefore influence their buying behavior. Therefore, reducing these risks would be an incentive for consumers to buy more secure devices. One of the analyzed studies [143] showed that people who receive security information (for example, using a label) may be influenced in their purchasing choices.

In the new "4.0 market", the investigation of consumer opinions will use data mining techniques much more intensively, improving the calculation tools used by marketers [74]. Consumers' willingness to use mobile applications dedicated to the information process and acquisition will also contribute to increasing the efficiency of consumer research and marketing content.

Technology is increasingly contributing to the delivery of information to the end-user. An illustrative example is Virtual Reality (VR) technology [140]. This technology can significantly increase the efficiency in the presentation of new products, improving communication and content delivery, and facilitating the flow of information between different entities in the market, which positively affects consumer behavior and their perception of products.

The smart environment is accelerating changes in customer behavior. In addition, the customer experience can be enhanced with the help of data extraction technology. While e-commerce is booming, the problem of "information overload" arises, which also causes problems for customers and companies. This problem can be solved with the e-commerce recommendation system. It can recommend information about products that meet the consumer's consumer preferences towards the target customer [137].

The widespread introduction of the Internet has had a positive impact on buying intentions, but not on trust in websites. Moreover, there are studies which have shown that there is a negative relationship between ease of use of a site and trust in that site. Three significant implications result from this, as follows: (1) The more a consumer appreciates a website for efficiency and ease of navigation, the less likely it is for the consumer to trust and submit personal information to the site. (2) The ease of use of a website is strongly correlated directly with the purchase intention. (3) There is a relationship between the skills of internet consumers and the confidence of the website, which implies that the better a person's skills using the Internet, the less resistant they are to online shopping. This is because 
ease of use strongly refers to the intention to purchase and may even compensate for the lack of trust that consumers may feel towards a website [123].

Consumers are increasingly using mobile devices while shopping. This behavior allows retailers to collect data on each purchase and type of consumer (age, gender, etc.), and to create databases that will later help marketing teams to improve the marketing mix [92].

On the other hand, intelligent technology brings benefits to customers in terms of increasing their information possibilities, both on the production process of the product and its use concerning their behavioral patterns [63].

The use of IoT changes the way manufacturers communicate with consumers, which becomes much more personal, increasing the accuracy of segmentation and targeting the desired audience. It can even be considered an entirely new type of direct marketing [92]. This feature can become a prerequisite for more sophisticated personalized marketing. IoT allows the creation of large networks, which will connect people, equipment, organizations, remodeling not only the style of communication and product promotion but also the expectations, perceptions and requirements of consumers to companies [92]. This will affect buying and consuming behavior.

The introduction of IoT and big data technologies has led to the growth of e-commerce. Consumer online shopping performance has improved due to the diversification of information sources. On the other hand, Fu et al. [136] have shown that the decision-making process on consumer behavior seems to be influenced by online consumer reviews.

The application of IoT technology is also useful for mobile commerce. Thus, the use of location-based services allows users to receive integrated information based on time, location and context, streamlining the shopping experience. Companies can use external incentives to get consumers to have a positive attitude towards using applications, which can affect their subsequent behavioral intent [138].

IT, IoT, digitalization, increasing population mobility and its heterogeneity contribute to changing social behavior. Thus, if in the past, certain activities (work, school, shopping, socializing) tended to take place at certain times and places, today they take place more and more in the pattern "anytime, anyplace" [114]. In addition, while previously these activities tended to be carried out "at a given time", in industry stage 4.0 work activities, shopping and personal/social activities become interactive, with the possibility of overlapping several activities in the same time frame, determining a new form of consumption, namely, collaborative consumption.

In the field of health services, the implementation of IT can bring specific benefits, both in terms of service quality and safety. The effectiveness of medical services can increase through personalization of behavioral health care [131]. The challenges facing IT in this area are significant in the field of behavioral health, due to difficulties in data standardization, lack of training of the IT provider for health, and mitigation of privacy issues. In the field of health, the implementation of Industry 4.0 technologies aims mainly at the more efficient use of available treatments and the promotion of patient-centered care. Regular use of various technologies in everyday life motivates health care providers to use technology appropriately to improve health services $[115,132]$. Understanding people's new habits can help create a better perspective for healthcare providers through online communication.

New technologies often change customer behavior, and artificial intelligence, even more so. AI seems to facilitate both marketers and their target audience. The former benefit from a huge volume of data for the study, and the latter benefit from reduced search costs. Studies have shown, however, that there are different degrees of influence, depending on how and when clients relate to artificial intelligence, namely the adoption of AI, the use of AI and the post-adoption of AI stage. In the stage of using AI, when clients interact with it, a low-level constructive mentality could be created. It remains to be seen what other mindsets could be determined by the AI or how an AI application should communicate with clients because communication has more substantial impacts when it matches the mindset. Davenport et al. [142] have suggested that in the phase of post-adoption of AI, clients may 
perceive a loss of autonomy if AI can substantially predict their preferences, as a result of which they may exhibit incorrect behaviors.

\subsection{Limitations}

This study presents some limitations. Regarding the search for information in articles, there is a limitation in not including articles that are not open access because of budgetary constraints. In the first search, including articles that are not open access, 2204 titles were provided. Only 762 were maintained in the analysis, satisfying the open-access condition.

\section{Conclusions}

\subsection{Opportunities and Challenges for New Directions in Education in Industry 4.0 Stage}

New technologies, mainly digitalization, information technology, and communication technology are changing how corporations produce and deliver customer service.

The development of human capital has generated, in this way, an innovative solution. Martiskova et al. [37] have stated that nowadays, human capital is not only creative but also is a super human capital.

At the heart of the 4.0 revolution is the information and communications technology, which, together with artificial intelligence, profoundly influences the economic-social environment, the life of each individual and the relationships established on a global scale. In the next decades, certain professions will be gradually taken over by industrial robots, so that a large part of the jobs will be affected. Thus, traditional roles in production, agriculture, utilities will disappear [146], but new jobs in health, education, and service delivery will emerge. However, these new jobs will require employees to acquire new skills, especially digital ones. Nowadays, the employees who are most afraid of job automation are those whose formal education is precarious. Continuous retraining of employees is the most commonly used method to reduce skill differences.

Companies need to get involved and support education. Governments must support continuing education programs. Industry 4.0 needs Education 4.0. To meet the needs of the economy in the future, Education 4.0 must be viewed from a four-dimensional perspective: vocational education, entrepreneurial education, financial education, and digital education.

\subsection{Identified Drivers for Human Capital Development and Consumer Behavior in Context of Industry 4.0 Revolution}

As Figure 4a shows, the analysis performed on the 111 studies, highlighted some key aspects for the development of human capital in the industry stage 4.0: information, new jobs, Internet, technology, training, education, new skills, automation, communication, innovativeness, professionals, productivity, artificial intelligence, digitalization, e-recruitment, and the Internet of Things. These factors contribute to the development of human capital in three directions, namely: (1) Reducing the number of jobs allocated to human labor; (2) Allocating a labor force to other areas that produce higher added value; (3) Increasing the demand for a labor force endowed with the skills required by new technologies. 


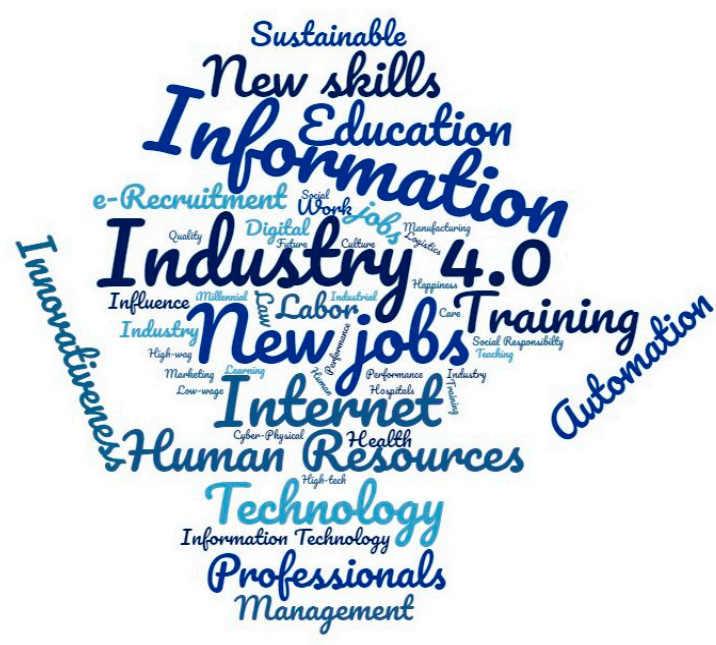

(a)

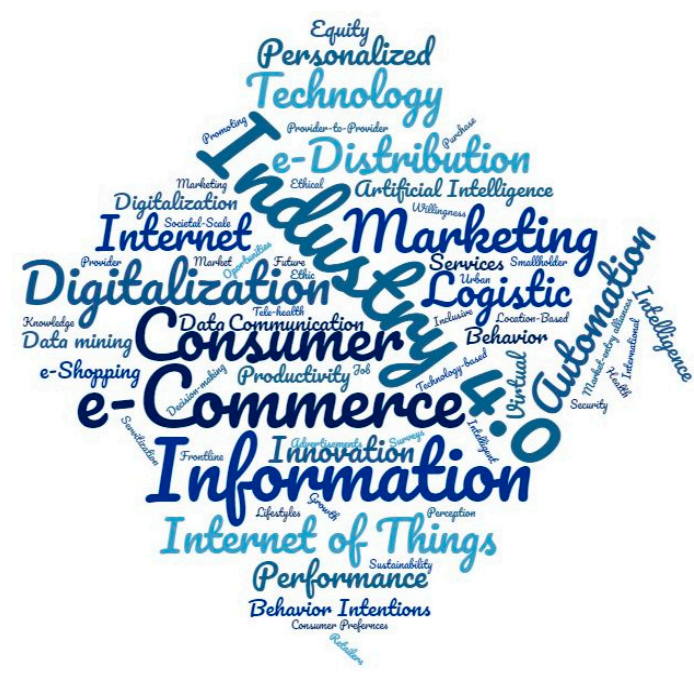

(b)

Figure 4. Word clouds arranged by area from the analyzed papers, based on word frequency in analyzed papers.

Figure $4 \mathrm{~b}$ displays the main drivers for consumer behavior in context of industy 4.0 revolution: Information, e-commerce, digitalization, Internet of Things, e-distribution, technology, automation, personalized, performance, artificial intelligence, behavior intention, e-shopping, and data mining. These driver factors contribute to consumer behavior reshaping from four perspectives, namely: (1) Business model innovation; (2) New market trends in which online commerce is becoming increasingly important; (3) Increasing access to information and the increased volume of data with which both consumers and producers are bombarded; (4) Increasing pressure from competitors.

The economic development of the last decades has depended on the competitive advantage created by the cheap and skilled workforce. In the digital age, this advantage has eroded because the workforce must be highly qualified and ready to develop new skills. The changes generated by the industry 4.0 revolution require the adoption of new business models, production processes, and new curriculums in academic programs.

Author Contributions: V.S., I.G.G., J.S. and D.N. were involved in the documentation phase, in choosing the research methodology, in records' selection and analysis, as well as in results analysis and discussions. All authors participated in the manuscript preparation and approved the submitted manuscript.

Funding: This research received no external funding.

Conflicts of Interest: The authors declare no conflict of interest.

\section{References}

1. Roşca, C.A. Locuri, oameni şi industrii: Rolul producţiei în oraş. Revista Şcolii Doctorale de Urbanism $2016,1,1$.

2. Frey, C.B.; Osborne, M. The future of employment: How susceptible are jobs to computerisation? Technol. Forecast. Soc. Chang. 2017, 114, 254-280. [CrossRef]

3. Bulte, A.T. What is Industry 4.0 and what are its Implications on HRM Practices? Bachelor's Thesis, University of Twente, Enschede, The Netherlands, 2018.

4. Poliak, M.; Tomicova, J.; Cheu, R.L.; Fedorko, G.; Poliakova, A. The Impact of the CMR Protocol on Carrier Competitiveness. J. Compet. 2019, 11, 132-143. [CrossRef]

5. Banabic, D. Evoluţia tehnicii şi tehnologiilor de la prima la a patra revoluţie industrială şi impactul lor social. In Discurs de recepţie în Academia Română; The Romanian Academy: Bucharest, Romania, 2018.

6. Mumford, L. The City in History: Its Origins, its Transformations, and its Prospects; Houghton Mifflin Harcourt: Boston, MA, USA, 1961; Volume 67. 
7. Tay, S.I.; Lee, T.C.; Hamid, N.Z.; Ahmad, A.N. An overview of industry 4.0: Definition, components, and government initiatives. J. Adv. Res. Dyn. Control Syst. 2018, 10, 1379-1387.

8. Fernández-Miranda, S.S.; Marcos, M.; Peralta-Alvarez, M.E.; Aguayo, F. The challenge of integrating Industry 4.0 in the degree of Mechanical Engineering. Procedia Manuf. 2017, 13, 1229-1236. [CrossRef]

9. Kagermann, H.; Lukas, W.-D.; Wahlster, W. Industrie 4.0: Mit dem Internet der Dinge auf dem Weg zur 4. industriellen Revolution. VDI Nachr. 2011, 13, 2.

10. Kagermann, H.; Helbig, J.; Hellinger, A.; Wahlster, W. Recommendations for Implementing the Strategic Initiative INDUSTRIE 4.0: Securing the Future of German Manufacturing Industry; Final Report of the Industrie 4.0 Working Group; Forschungsunion: Berlin, Germany, 2013; pp. 19-26.

11. Qin, J.; Liu, Y.; Grosvenor, R. A Categorical Framework of Manufacturing for Industry 4.0 and Beyond. Procedia CIRP 2016, 52, 173-178. [CrossRef]

12. Schumacher, A.; Erol, S.; Sihn, W. A Maturity Model for Assessing Industry 4.0 Readiness and Maturity of Manufacturing Enterprises. Procedia CIRP 2016, 52, 161-166. [CrossRef]

13. Nagy, J.; Oláh, J.; Erdei, E.; Máté, D.; Popp, J. The Role and Impact of Industry 4.0 and the Internet of Things on the Business Strategy of the Value Chain-The Case of Hungary. Sustainability 2018, 10, 3491. [CrossRef]

14. Vaidya, S.; Ambad, P.; Bhosle, S. Industry 4.0-A Glimpse. Procedia Manuf. 2018, 20, 233-238. [CrossRef]

15. Schwab, K. The fourth Industrial Revolution; World Economic Forum: Geneva, Switzerland, 2017.

16. Wang, S.; Wan, J.; Li, D.; Zhang, C. Implementing Smart Factory of Industrie 4.0: An Outlook. Int. J. Distrib. Sens. Netw. 2016, 12, 3159805-3159810. [CrossRef]

17. Kicová, M. Enterprise's process innovations in the context of enterprise's financial performance. Strat. Manag. 2019, 24, 3-13. [CrossRef]

18. Miller, A.; Miller, M. Study of the problems of technological integration in the manufacturing industry in Russia. Strat. Manag. 2019, 24, 33-42. [CrossRef]

19. Ślusarczyk, B. Industry 4.0-Are we ready? Pol. J. Manag. Stud. 2018, 17, 232-248. [CrossRef]

20. Wyrwicka, M.; Mrugalska, B. "Industry 4.0"-Towards Opportunities and Challanges of Implementation. In Proceedings of the 24th International Conference on Production Research, Poznan, Poland, July 30-3 August 2017; DEStech Publications: Lancaster, PA, USA; pp. 382-387.

21. Dragičević, Z.; Bošnjak, S. Agile architecture in the digital era: Trends and practices. Strat. Manag. 2019, 24, 12-33. [CrossRef]

22. Vochozka, M.; Klieštik, T.; Klieštiková, J.; Sion, G. Participating in a highly automated society: How artificial intelligence disrupts the job market. Econ. Manag. Financ. Mark. 2018, 13, 57-62.

23. Leonhard, G. Technology vs. Humanity; Fast Future Publishing: Tonbridge, UK, 2017.

24. Erol, S.; Jäger, A.; Hold, P.; Ott, K.; Sihn, W. Tangible Industry 4.0: A Scenario-Based Approach to Learning for the Future of Production. Procedia CIRP 2016, 54, 13-18. [CrossRef]

25. Industrial Revolution 4.0: The Human Resource Practices. Int. J. Recent Technol. Eng. 2019, 8, 620-624. [CrossRef]

26. Ahmad, N.; Shamsuddin, A.; Aslinda, A.S. Industry 4.0 Implications on Human Capital: A Review. J. Stud. Manag. Plan. 2018, 4, 220-235. Available online: https://pen2print.org/index.php/jsmap/issue/view/252 (accessed on 22 April 2020).

27. Kolesnichenko, E.; Radyukova, Y.; Pakhomov, N. The Role and Importance of Knowledge Economy as a Platform for Formation of Industry 4.0. In Industry 4.0: Industrial Revolution of the 21st Century. Studies in Systems, Decision and Control; Popkova, E., Ragulina, Y., Bogoviz, A., Eds.; Springer: Berlin/Heidelberg, Germany, 2019; pp. 73-82. [CrossRef]

28. Petrov, V.; Ćelić, Đ.; Uzelac, Z.; Drašković, Z. Specific influence of knowledge intensive and capital intensive organizations on collaborative climate and knowledge sharing in SMEs. Strat. Manag. 2020, 25, 3-11. [CrossRef]

29. Sima, V.; Gheorghe, I.G. Labour market trends in România in the context of green economy. In Annals of the "Constantin Brâncuşiı"; University of Târgu Jiu: Târgu Jiu, Romania, 2014; pp. 116-123.

30. Da Silva, V.L.; Kovaleski, J.L.; Pagani, R.N. Technology Transfer and Human Capital in the Industrial 4.0 Scenario: A Theoretical Study. Futur. Stud. Res. J. Trends Strat. 2019, 11, 102-122. [CrossRef] 
31. Kinzel, H. Industry 4.0-Where does this leave the Human Factor? J. Urban Cult. Res. 2017, 15, 70-83. [CrossRef]

32. Pantano, E.; Di Pietro, L. Understanding Consumer's Acceptance of Technology-Based Innovations in Retailing. J. Technol. Manag. Innov. 2012, 7, 1-19. [CrossRef]

33. Sima, V.; Gheorghe, I.G. Changing Consumption Patterns in Green Economy. In Agricultural Management Strategies in a Changing Economy; Popescu, G., Andrei, J.-V., Eds.; IGI Global: Hershey, PA, USA, 2015; pp. 186-212. [CrossRef]

34. Sorescu, A.; Frambach, R.T.; Singh, J.; Rangaswamy, A.; Bridges, C. Innovations in Retail Business Models. J. Retail. 2011, 87, S3-S16. [CrossRef]

35. Graessley, S.; Horak, J.; Kovacova, M.; Valaskova, K.; Poliak, M.J. Consumer attitudes and behaviors in the technology-driven sharing economy: Motivations for participating in collaborative consumption. J. Self-Gov. Manag. Econ. 2019, 7, 25-30.

36. Dadwal, S.S. Handbook of Research on Innovations in Technology and Marketing for the Connected Consumer; IGI Global: Hershey, PA, USA, 2020. [CrossRef]

37. Martiskova, P.; Svec, R. Digital Era and Consumer Behavior on the Internet. In Digital Age: Chances, Challenges and Future; Ashmarina, S.I., Vochozka, M., Mantulenko, V.V., Eds.; Springer: Berlin/Heidelberg, Germany, 2020; pp. 92-100.

38. Agolla, J.E. Human Capital in the Smart Manufacturing and Industry 4.0 Revolution. In Digital Transformation in Smart Manufacturing; Petrillo, A., Cioffi, R., Felice, D., Fabio, Eds.; IntechOpen: London, UK, 2018; pp. $44-51$.

39. Rüßmann, M.; Lorenz, M.; Gerbert, P.; Waldner, M.; Justus, J.; Engel, P.; Harnisch, M. Industry 4.0: The future of productivity and growth in manufacturing industries. Boston Consult. Group 2015, 9, 54-89.

40. Hecklau, F.; Galeitzke, M.; Flachs, S.; Kohl, H. Holistic Approach for Human Resource Management in Industry 4.0. Procedia CIRP 2016, 54,1-6. [CrossRef]

41. Moher, D.; Liberati, A.; Tetzlaff, J.; Altman, D.G. The PRISMA Group. Preferred Reporting Items for Systematic Reviews and Meta-Analyses: The PRISMA Statement. PLoS Med. 2009, 6, e1000097. [CrossRef]

42. Liberati, A.; Altman, U.G.; Tetzlaff, J.; Mulrow, C.; Gøtzsche, P.C.; Ioannidis, J.P.; Clarke, M.; Devereaux, P.J.; Kleijnen, J.; Moher, D. The PRISMA statement for reporting systematic reviews and meta-analyses of studies that evaluate healthcare interventions: Explanation and elaboration. BMJ 2009, 339, b2700. [CrossRef]

43. Mariano, D.C.B.; Leite, C.; Santos, L.H.S.; Rocha, R.E.O.; De Melo-Minardi, R.C. A Guide to Performing Systematic Literature Reviews in Bioinformatics. arXiv 2017, arXiv:1707.05813.

44. Davis, J.T.M.; Mengersen, K.L.; Bennett, S.; Mazerolle, L. Viewing systematic reviews and meta-analysis in social research through different lenses. SpringerPlus 2014, 3, 511. [CrossRef] [PubMed]

45. Snyder, H. Literature review as a research methodology: An overview and guidelines. J. Bus. Res. 2019, 104, 333-339. [CrossRef]

46. Lovric, L. Information-communication technology impact on labor productivity growth of EU developing countries. J. Econ. Bus. 2012, 30, 223-245.

47. Büchi, G.; Cugno, M.; Castagnoli, R. Smart factory performance and Industry 4.0. Technol. Forecast. Soc. Chang. 2020, 150, 119790. [CrossRef]

48. Valaskova, K.; Kliestik, T.; Kovacova, M. Management of financial risks in Slovak enterprises using regression analysis. Oeconomia Copernic. 2018, 9, 105-121. [CrossRef]

49. Kral, P.; Valjaskova, V.; Janoskova, K. Quantitative approach to project portfolio management: Proposal for Slovak companies. Oeconomia Copernic. 2019, 10, 797-814. [CrossRef]

50. Chovancova, B.; Dorocakova, M.; Malacka, V. Changes in the industrial structure of GDP and stock indices also with regard to industry 4.0. Bus. Econ. Horiz. 2018, 14, 402-414. [CrossRef]

51. Sung, T.K. Industry 4.0: A Korea perspective. Technol. Forecast. Soc. Chang. 2018, 132, 40-45. [CrossRef]

52. Haseeb, M.; Sasmoko; Mihardjo, L.W.W.; Jermsittiparsert, K. Economic Impact of Artificial Intelligence: New Look for the Macroeconomic Assessment in Asia-Pacific Region. Int. J. Comput. Intell. Syst. 2019, 12, 1295-1310. [CrossRef] 
53. Autor, D.H. Why Are There Still So Many Jobs? The History and Future of Workplace Automation. J. Econ. Perspect. 2015, 29, 3-30. [CrossRef]

54. Ranzatti, M.A.; Rosini, A.M.; Da Silva, O.R.; Palmisano, A.; Guevara, A.J.H. A Quantitative Perspective of the Implementation of Best Practices on Itil: Information Technology Infrastructure Library in a Brazilian Public Company under People and Processes Overview. J. Innov. Sustain. 2019, 10, 13-11. [CrossRef]

55. Charalampidis, N. The U.S. Labor income share and automation shocks. Econ. Inq. 2019, 58, $294-318$. [CrossRef]

56. Eichhorst, W.; Hinte, H.; Rinne, U.; Tobsch, V. How Big is the Gig? Assessing the Preliminary Evidence on the Effects of Digitalization on the Labor Market. Manag. Rev. 2017, 28, 298-318. [CrossRef]

57. Bejtkovský, J.; Rózsa, Z.; Mulyaningsih, H.D. A phenomenon of digitalization and E-recruitment in business environment. Pol. J. Manag. Stud. 2018, 18, 58-68. [CrossRef]

58. Kornelakis, A.; Petrakaki, D. Embedding employability skills in UK higher education: Between digitalization and marketization. Ind. High. Educ. 2020. [CrossRef]

59. Sorgner, A. The Automation of Jobs: A Threat for Employment or a Source of New Entrepreneurial Opportunities? Foresight STI Gov. 2017, 11,37-48. [CrossRef]

60. Ivanova, V.N.; Poltarykhin, A.L.; Szromnik, A.; Anichkina, O. Economic policy for country's digitalization: A case study. Entrep. Sustain. Issues 2019, 7, 649-661. [CrossRef]

61. Kunanets, N.E.; Nazaruk, M.V.; Nebesnyi, R.M.; Pasichnyk, V.V. Information technology of personalized choice of profession in smart cities. Інформаційні технології і засоби навчання. 2018, 65, 277-290. [CrossRef]

62. Wagner, D.N. Economic patterns in a world with artificial intelligence. Evol. Inst. Econ. Rev. 2020, 17, 111-131. [CrossRef]

63. Dedrick, J.; Kraemer, K.L.; Shih, E. Information Technology and Productivity in Developed and Developing Countries. J. Manag. Inf. Syst. 2013, 30, 97-122. [CrossRef]

64. Kampa, A.; Golda, G. Modelling and Simulation Method for Production Process Automation in Steel Casting Foundry. Arch. Foundry Eng. 2018, 18, 47-52. [CrossRef]

65. Petroutsatou, K.; Sifiniadis, A. Exploring the consequences of human multitasking in industrial automation projects: A tool to mitigate impacts-Part II. Organ. Technol. Manag. Constr. Int. J. 2018, 10, 1770-1777. [CrossRef]

66. Gerlick, J.A.; Liozu, S.M. Ethical and legal considerations of artificial intelligence and algorithmic decision-making in personalized pricing. J. Revenue Pricing Manag. 2020, 19, 85-98. [CrossRef]

67. Chakraborty, S.; Bhojwani, R. Artificial Intelligence and Human Rights: Are they convergent or parallel to each other? Novum Jus 2018, 12, 14-42. [CrossRef]

68. Stefancic, M.; Zirnstein, E. The Impact of Digital Technologies and Digitalization on Labour Law: The Case of Slovenia. Lexonomica 2018, 10, 119-132. [CrossRef]

69. Frank, M.R.; Autor, D.; Bessen, J.E.; Brynjolfsson, E.; Cebrian, M.; Deming, D.J.; Feldman, M.; Groh, M.; Lobo, J.; Moro, E.; et al. Toward understanding the impact of artificial intelligence on labor. Proc. Natl. Acad. Sci. USA 2019, 116, 6531-6539. [CrossRef]

70. Ogutu, S.O.; Okello, J.J.; Otieno, D.J. Impact of Information and Communication Technology-Based Market Information Services on Smallholder Farm Input Use and Productivity: The Case of Kenya. World Dev. 2014, 64, 311-321. [CrossRef]

71. Montgomery, K.; Chester, J.; Kopp, K. Kopp Health Wearables: Ensuring Fairness, Preventing Discrimination, and Promoting Equity in an Emerging Internet-of-Things Environment. J. Inf. Policy 2018, 8, 34-77. [CrossRef]

72. Arnold, C.; Kiel, D.; Voigt, K.-I. How Industry 4.0 changes business models in different manufacturing industries. In Proceedings of the XXVII ISPIM Innovation Conference-Blending Tomorrow's Innovation Vintage, Porto, Portugal, 19-22 June 2016.

73. Frank, A.G.; Mendes, G.; Ayala, N.F.; Ghezzi, A. Servitization and Industry 4.0 convergence in the digital transformation of product firms: A business model innovation perspective. Technol. Forecast. Soc. Chang. 2019, 141, 341-351. [CrossRef]

74. Dubé, L.; Du, P.; McRae, C.; Sharma, N.; Jayaraman, S.; Nie, J.-Y. Convergent Innovation in Food through Big Data and Artificial Intelligence for Societal-Scale Inclusive Growth. Technol. Innov. Manag. Rev. 2018, 8, 49-65. [CrossRef] 
75. Fantini, P.; Pinzone, M.; Taisch, M. Placing the operator at the centre of Industry 4.0 design: Modelling and assessing human activities within cyber-physical systems. Comput. Ind. Eng. 2020, 139, 105058. [CrossRef]

76. Gerlitz, L. Design management as a domain of smart and sustainable enterprise: Business modelling for innovation and smart growth in Industry 4.0. Entrep. Sustain. Issues 2016, 3, 244-268. [CrossRef]

77. Mohelská, H.; Sokolova, M. Management Approaches for Industry 4.0-The Organizational Culture Perspective. Technol. Econ. Dev. Econ. 2018, 24, 2225-2240. [CrossRef]

78. Palazzeschi, L.; Bucci, O.; Di Fabio, A. Re-thinking Innovation in Organizations in the Industry 4.0 Scenario: New Challenges in a Primary Prevention Perspective. Front. Psychol. 2018, 9, 9. [CrossRef] [PubMed]

79. Kiel, D.; Müller, J.M.; Arnold, C.; Voigt, K.-I. Sustainable Industrial Value Creation: Benefits and Challenges of Industry 4.0. Int. J. Innov. Manag. 2017, 21, 1740015. [CrossRef]

80. Laudien, S.M.; Daxböck, B. The influence of the industrial internet of things on business model design: A qualitative-empirical analysis. Int. J. Innov. Manag. 2016, 20, 1640014. [CrossRef]

81. Müller, J.M.; Voigt, K.-I. Sustainable Industrial Value Creation in SMEs: A Comparison between Industry 4.0 and Made in China 2025. Int. J. Precis. Eng. Manuf. Technol. 2018, 5, 659-670. [CrossRef]

82. Prem, E. Artificial Intelligence for Innovation in Austria. Technol. Innov. Manag. Rev. 2019, 9, 5-15. [CrossRef]

83. Saucedo-Martínez, J.A.; Lara, M.P.; Marmolejo-Saucedo, J.; Salais-Fierro, T.E.; Vasant, P. Industry 4.0 framework for management and operations: A review. J. Ambient. Intell. Humaniz. Comput. 2017, 9, 789-801. [CrossRef]

84. Chen, S.; Wei, S.; Zhang, H.; Gao, Y. Spatiotemporal Evolution of the Taiwanese-Funded Information Technology and Electronics Industry Value Chain in Mainland China. Sustainability 2019, 11, 3214. [CrossRef]

85. Barata, J.; Da Cunha, P.R.; Stal, J. Mobile supply chain management in the Industry 4.0 era. J. Enterp. Inf. Manag. 2018, 31, 173-192. [CrossRef]

86. Da Silva, V.L.; Kovaleski, J.L.; Pagani, R.N. Technology transfer in the supply chain oriented to industry 4.0: A literature review. Technol. Anal. Strat. Manag. 2018, 31, 546-562. [CrossRef]

87. Hoßfeld, S. Optimization on Decision Making Driven by Digitalization. Econ. World 2017, 5, 120-128. [CrossRef]

88. Krykavskyi, Y.; Pokhylchenko, E.; Hayvanovych, N. Supply chain development drivers in industry 4.0 in Ukrainian enterprises. Oeconomia Copernic. 2019, 10, 273-290. [CrossRef]

89. Sanchez, E.G.; Guerrero-Villegas, J.; Aguilera-Caracuel, J. How Do Technological Skills Improve Reverse Logistics? The Moderating Role of Top Management Support in Information Technology Use and Innovativeness. Sustainability 2018, 11, 58. [CrossRef]

90. Porter, M.E.; Heppelmann, J.E. How smart, connected products are transforming competition. Harv. Bus. Rev. 2014, 92, 64-88. Available online: https://hbr.org/2014/11/how-smart-connected-products-are-transformingcompetition (accessed on 21 February 2020).

91. Byun, S. Evaluating Information Technology Systems Using Consumer Surveys: The Role of Personal Product Knowledge. J. Asian Financ. Econ. Bus. 2018, 5, 117-125. [CrossRef]

92. Abashidze, I.; Dabrowski, M. Internet of Things in Marketing: Opportunities and Security Issues. Manag. Syst. Prod. Eng. 2016, 24, 217-221. [CrossRef]

93. Nafchi, M.Z.; Mohelská, H. Effects of Industry 4.0 on the Labor Markets of Iran and Japan. Economies 2018, 6, 39. [CrossRef]

94. Stachova, K.; Papula, J.; Stacho, Z.; Kohnová, L. External Partnerships in Employee Education and Development as the Key to Facing Industry 4.0 Challenges. Sustainability 2019, 11, 345. [CrossRef]

95. Cotet, G.B.; Carutasu, N.L.; Chiscop, F. Industry 4.0 Diagnosis from an iMillennial Educational Perspective. Educ. Sci. 2020, 10, 21. [CrossRef]

96. Kergroach, S. Industry 4.0: New Challenges and Opportunities for the Labour Market. Foresight STI Gov. 2017, 11, 6-8. [CrossRef]

97. Strauch, B. The Automation-by-Expertise-by-Training Interaction. Hum. Factors J. Hum. Factors Ergon. Soc. 2016, 59, 204-228. [CrossRef] [PubMed]

98. Sugandi, L.; Kurniawan, Y. The Influence of Information Technology on the Information and Service Quality for the Teaching and Learning. Int. J. Emerg. Technol. Learn. (iJET) 2018, 13, 230-237. [CrossRef] 
99. Krzywdzinski, M. Automation, skill requirements and labour-use strategies: High-wage and low-wage approaches to high-tech manufacturing in the automotive industry. New Technol. Work. Employ. 2017, 32, 247-267. [CrossRef]

100. Agrawal, A.; Gans, J.S.; Goldfarb, A. Artificial Intelligence: The Ambiguous Labor Market Impact of Automating Prediction. J. Econ. Perspect. 2019, 33, 31-50. [CrossRef]

101. Pan, M.; Sikorski, J.; Kastner, C.A.; Akroyd, J.; Mosbach, S.; Lau, R.; Kraft, M. Applying Industry 4.0 to the Jurong Island Eco-industrial Park. Energy Procedia 2015, 75, 1536-1541. [CrossRef]

102. Weller, S.I. Influence of Digitalization on the Tasks of Employees with Disabilities in Germany (1979-2006). Societes 2019, 9, 18. [CrossRef]

103. Reynolds, E.B.; Uygun, Y. Strengthening advanced manufacturing innovation ecosystems: The case of Massachusetts. Technol. Forecast. Soc. Chang. 2017, 136, 178-191. [CrossRef]

104. Kovacs, G.; Kot, S. New Logistics and Production Trends as the Effect of Global Economy Changes. Pol. J. Manag. Stud. 2016, 14, 115-126. [CrossRef]

105. Jančíková, K.; Milichovský, F. HR Marketing as a Supporting Tool of New Managerial Staff in Industry 4.0. Adm. Sci. 2019, 9, 60. [CrossRef]

106. Fischer, G.S.; Righi, R.D.R.; Ramos, G.D.O.; Da Costa, C.A.; Rodrigues, J.J. ElHealth: Using Internet of Things and data prediction for elastic management of human resources in smart hospitals. Eng. Appl. Artif. Intell. 2020, 87, 103285. [CrossRef]

107. Pejic-Bach, M.; Bertoncel, T.; Meško, M.; Krstić, Ž. Text mining of industry 4.0 job advertisements. Int. J. Inf. Manag. 2020, 50, 416-431. [CrossRef]

108. Šerić, M.; Gil Saura, I.; Praničević, D.G. Latest technology and communication consistency in hospitality: A comparison between two Mediterranean countries. Econ. Res. 2016, 29, 1091-1108. [CrossRef]

109. Ravina-Ripoll, R.; Domínguez, J.M.; Del Rio, M.; Ángel, M. Happiness Management en la época de la Industria 4.0. Retos 2019, 9, 189-202. [CrossRef]

110. Quinn, J.; Frias-Martinez, V.; Subramanian, L. Computational Sustainability and Artificial Intelligence in the Developing World. AI Mag. 2014, 35, 36. [CrossRef]

111. Müller, J.M.; Buliga, O.; Voigt, K.-I. Fortune favors the prepared: How SMEs approach business model innovations in Industry 4.0. Technol. Forecast. Soc. Chang. 2018, 132, 2-17. [CrossRef]

112. Birkel, H.; Veile, J.W.; Müller, J.M.; Hartmann, E.; Voigt, K.-I. Development of a Risk Framework for Industry 4.0 in the Context of Sustainability for Established Manufacturers. Sustainability 2019, 11, 384. [CrossRef]

113. Pashaki, Y.K. The Role of the Use of Information and Communication Technology Skills on the Share of Productivity Components of Human Resources for the Improvement of the Functional System of Management of the Department of Power Distribution Centers in Districts of Guilan Province. Revista Gestão Tecnologia 2018, 18, 49-66. [CrossRef]

114. Lyons, G.; Mokhtarian, P.; Dijst, M.; Böcker, L. The dynamics of urban metabolism in the face of digitalization and changing lifestyles: Understanding and influencing our cities. Resour. Conserv. Recycl. 2018, 132, $246-257$. [CrossRef]

115. Tao, D.; Shao, F.; Wang, H.; Yan, M.; Qu, X. Integrating usability and social cognitive theories with the technology acceptance model to understand young users' acceptance of a health information portal. Health Inform. J. 2019, 16. Available online: https://journals.sagepub.com/doi/full/10.1177/1460458219879337 (accessed on 18 February 2020). [CrossRef] [PubMed]

116. Deaconu, A.; Dedu, E.M.; Igret, R.S.; Radu, C. The Use of Information and Communications Technology in Vocational Education and Training-Premise of Sustainability. Sustainability 2018, 10, 1466. [CrossRef]

117. Mamedov, O.; Tumanyan, Y.; Ishchenko-Padukova, O.; Movchan, I. Sustainable economic development and post-economy of artificial intelligence. Entrep. Sustain. Issues 2018, 6, 1028-1040. [CrossRef]

118. Zhao, H.; Zhao, Q.H.; Ślusarczyk, B. Sustainability and Digitalization of Corporate Management Based on Augmented/Virtual Reality Tools Usage: China and Other World IT Companies' Experience. Sustainability 2019, 11, 4717. [CrossRef]

119. Scavarda, A.; Daú, G.; Scavarda, L.F.; Caiado, R.G.G. An Analysis of the Corporate Social Responsibility and the Industry 4.0 with Focus on the Youth Generation: A Sustainable Human Resource Management Framework. Sustainability 2019, 11, 5130. [CrossRef] 
120. Chiarvesio, M.; Romanello, R. Industry 4.0 Technologies and Internationalization: Insights from Italian Companies. Prog. Int. Bus. Res. 2018, 13, 357-378. [CrossRef]

121. Zhao, S.; Priporas, C.-V. Information technology and marketing performance within international market-entry alliances. Int. Mark. Rev. 2017, 34, 5-28. [CrossRef]

122. Strange, R.; Zucchella, A. Industry 4.0, global value chains and international business. Multinatl. Bus. Rev. 2017, 25, 174-184. [CrossRef]

123. Lindh, C.; Nordman, E.R.; Hånell, S.M.; Safari, A.; Hadjikhani, A. Digitalization and International Online Sales: Antecedents of Purchase Intent. J. Int. Consum. Mark. 2020, 1-12. [CrossRef]

124. Dalenogare, L.S.; Benitez, G.B.; Ayala, N.F.; Frank, A.G. The expected contribution of Industry 4.0 technologies for industrial performance. Int. J. Prod. Econ. 2018, 204, 383-394. [CrossRef]

125. Cruz, A.C.; Tavares, L.D. Implementation of organizational climate survey for performance improvement and competitiveness of an information technology company. Sistemas Gestao 2016, 11, 290-298. [CrossRef]

126. Lee, J.; Bagheri, B.; Kao, H.-A. A Cyber-Physical Systems architecture for Industry 4.0-based manufacturing systems. Manuf. Lett. 2015, 3, 18-23. [CrossRef]

127. Misztal, A.; Butlewski, M.; Jasiak, A.; Janik, S. The human role in a progressive trend of foundry automation. Metalurgija 2015, 54, 429-432. Available online: https://hrcak.srce.hr/128980 (accessed on 18 February 2020).

128. Turulja, L.; Bajgorić, N. Human Resources or Information Technology: What is More Important for Companies in the Digital Era? Bus. Syst. Res. J. 2016, 7, 35-45. [CrossRef]

129. Ahmed, S.; Taskin, N.; Pauleen, D.J.; Parker, J. Motivating Information Technology Professionals: The case of New Zealand. Australas. J. Inf. Syst. 2017, 21, 21. [CrossRef]

130. Kim, J.; Park, H.-A.; Chiu, T. Development of a Health Information Technology Acceptance Model Using Consumers' Health Behavior Intention. J. Med. Internet Res. 2012, 14, e133. [CrossRef]

131. Ranallo, P.A.; Kilbourne, A.M.; Whatley, A.S.; Pincus, H.A. Behavioral Health Information Technology: From Chaos to Clarity. Health Aff. 2016, 35, 1106-1113. [CrossRef]

132. Hah, H.; Goldin, D.; Ha, S. Title Correction: The Association Between Willingness of Frontline Care Providers' to Adaptively Use Telehealth Technology and Virtual Service Performance in Provider-to-Provider Communication: Quantitative Study. J. Med. Internet Res. 2019, 21, e17123. [CrossRef]

133. Bakken, S.; Marden, S.; Arteaga, S.S.; Grossman, L.V.; Keselman, A.; Le, P.-T.; Creber, R.M.; Powell-Wiley, T.M.; Schnall, R.; Tabor, D.; et al. Behavioral Interventions Using Consumer Information Technology as Tools to Advance Health Equity. Am. J. Public Health 2019, 109, S79-S85. [CrossRef]

134. Mesko, B.; Hetényi, G.; Győrffy, Z. Will artificial intelligence solve the human resource crisis in healthcare? BMC Health Serv. Res. 2018, 18, 545. [CrossRef] [PubMed]

135. Chivu-Draghia, C.; Antoce, A.O. Consumer preferences regarding sources of information and use of technology for wine selection-a survey of millennials and generation X sample in Romania. Sci. Pap. Manag. Econ. Eng. 2016, 16, 65-74.

136. Fu, H.; Manogaran, G.; Wu, K.; Cao, M.; Jiang, S.; Yang, A. Intelligent decision-making of online shopping behavior based on internet of things. Int. J. Inf. Manag. 2020, 50, 515-525. [CrossRef]

137. Yan, Y.; Huang, C.; Wang, Q.; Hu, B. Data mining of customer choice behavior in internet of things within relationship network. Int. J. Inf. Manag. 2020, 50, 566-574. [CrossRef]

138. Tsai, Y.-T.; Wang, S.-C.; Yan, K.-Q.; Chang, C.-M. Precise Positioning of Marketing and Behavior Intentions of Location-Based Mobile Commerce in the Internet of Things. Symmetry 2017, 9, 139. [CrossRef]

139. Lee, W.; Shin, S. An empirical study of consumer adoption of Internet of Things services. Int. J. Eng. Technol. Innov. 2019, 9, 1-11.

140. Grudzewski, F.; Awdziej, M.; Mazurek, G.; Piotrowska, K. Virtual reality in marketing communication-The impact on the message, technology and offer perception-Empirical study. Econ. Bus. Rev. 2018, 4, 36-50. [CrossRef]

141. Simchi-Levi, D.; Wu, M.X. Powering retailers' digitization through analytics and automation. Int. J. Prod. Res. 2017, 56, 809-816. [CrossRef]

142. Davenport, T.; Guha, A.; Grewal, D.; Bressgott, T. How artificial intelligence will change the future of marketing. J. Acad. Mark. Sci. 2019, 48, 24-42. [CrossRef]

143. Blythe, J.M.; Johnson, S.D.; Manning, M. What is security worth to consumers? Investigating willingness to pay for secure Internet of Things devices. Crime Sci. 2020, 9, 1-9. [CrossRef] 
144. Wu, H.-L.; Chan, N.-K.; Zhang, C.J.P.; Ming, W.-K. The Role of the Sharing Economy and Artificial Intelligence in Health Care: Opportunities and Challenges. J. Med. Internet Res. 2019, 21, e13469. [CrossRef] [PubMed]

145. Subic, J.; Vasiljevic, Z.; Andrei, J.V. The impact of FDI on the European economic development in the context of diversification of capital flows. In Proceedings of the 14th International Business Information Management Association, Business Transformation through Innovation and Knowledge Management: An Academic Perspective, Istanbul, Turkey, 23-24 June 2010; pp. 23-24.

146. Popescu, G.; Andrei, J. From industrial holdings to subsistence farms in Romanian agriculture. Analyzing the subsistence components of CAP. Agric. Econ. 2011, 57, 555-564. [CrossRef]

(C) 2020 by the authors. Licensee MDPI, Basel, Switzerland. This article is an open access article distributed under the terms and conditions of the Creative Commons Attribution (CC BY) license (http://creativecommons.org/licenses/by/4.0/). 